Prepared in cooperation with the Hampton Roads Planning District Commission

\title{
Land Subsidence and Relative Sea-Level Rise in the Southern Chesapeake Bay Region
}

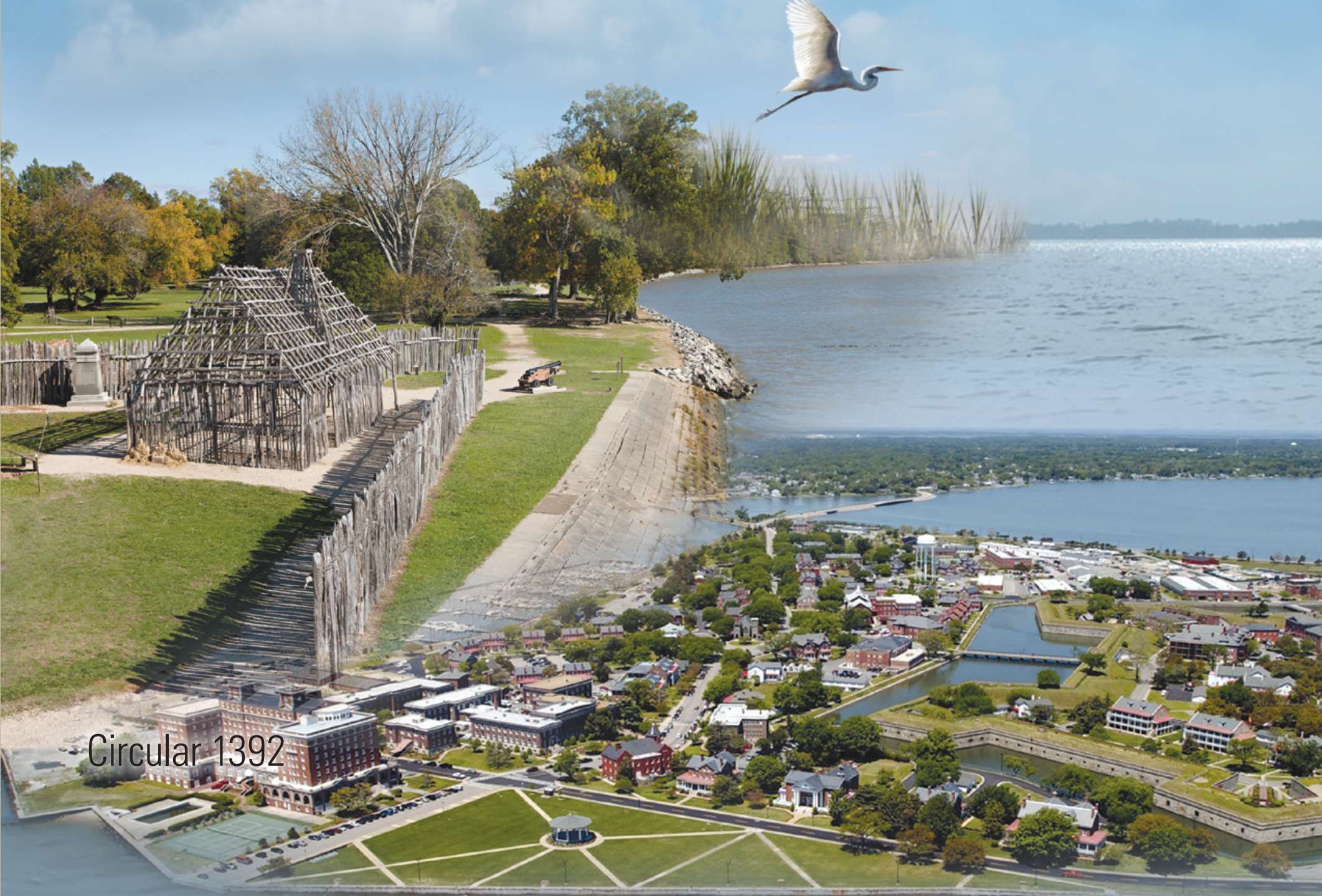

U.S. Department of the Interior

U.S. Geological Survey 
Cover: Photographs, top left, the constructed colonial-era fort wall in Jamestown, Virginia, next to the James River, photograph by Barbara Lombardi, courtesy of The Colonial Williamsburg Foundation; top right, a great egret takes to the air along the Lynnhaven River in Virginia Beach, photograph by L. Todd Spencer, The Virginian-Pilot, July 2010, used with permission; bottom, Fort Monroe in Hampton, Virginia, photograph by Stephen N. Katz, The Virginian-Pilot, May 2005, used with permission. 


\section{Land Subsidence and Relative Sea-Level Rise in the Southern Chesapeake Bay Region}

By Jack Eggleston and Jason Pope

Prepared in cooperation with the Hampton Roads Planning District Commission

Circular 1392 


\title{
U.S. Department of the Interior \\ SALLY JEWELL, Secretary
}

\author{
U.S. Geological Survey \\ Suzette M. Kimball, Acting Director
}

\section{U.S. Geological Survey, Reston, Virginia: 2013}

For more information on the USGS - the Federal source for science about the Earth, its natural and living resources, natural hazards, and the environment, visit http://www.usgs.gov or call 1-888-ASK-USGS.

For an overview of USGS information products, including maps, imagery, and publications, visit http://www.usgs.gov/pubprod

To order this and other USGS information products, visit http://store.usgs.gov

Any use of trade, firm, or product names is for descriptive purposes only and does not imply endorsement by the U.S. Government.

Although this information product, for the most part, is in the public domain, it also may contain copyrighted materials as noted in the text. Permission to reproduce copyrighted items must be secured from the copyright owner.

Suggested citation:

Eggleston, Jack, and Pope, Jason, 2013, Land subsidence and relative sea-level rise in the southern Chesapeake Bay region: U.S. Geological Survey Circular 1392, 30 p., http://dx.doi.org/10.3133/cir1392.

ISSN 1067-084X (print)

ISSN 2330-5703 (online)

ISBN 978-1-4113-3716-9

\section{Library of Congress Cataloging-in-Publication Data}

Eggleston, Jack.

Land subsidence and relative sea-level rise in the southern Chesapeake Bay region / by Jack Eggleston and Jason Pope ; prepared in cooperation with the Hampton Roads Planning District Commission.

pages $\mathrm{cm}$.-- (Circular; 1392)

Includes bibliographical references.

ISBN 978-1-4113-3716-9 (alk. paper)

1. Hydrogeology--Chesapeake Bay Region (Md. and Va.) 2. Subsidences (Earth movements)--Chesapeake Bay Region (Md. and Va.) 3. Sea level--Chesapeake Bay Region (Md. and Va.) 4. Groundwater--Chesapeake Bay Region (Md. and Va.) 5. Flood control--Chesapeake Bay Region (Md. and Va.) I. Pope, Jason P. II. Hampton Roads Planning District Commission (Va.) III. Title.

GB1016.6.E34 2014

$551.4909163^{\prime} 47--d c 23$ 


\section{Contents}

Description of Land Subsidence .............................................................................................

Why Land Subsidence is a Concern in the Southern Chesapeake Bay Region ..............................4

Land Subsidence Contributes to Relative Sea-Level Rise ..................................................

Land Subsidence Increases Flood Risk .............................................................................

Land Subsidence Can Damage Wetland and Coastal Marsh Ecosystems...............................6

Land Subsidence Can Damage Infrastructure ..........................................................................6

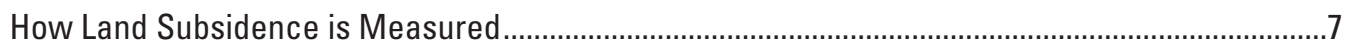

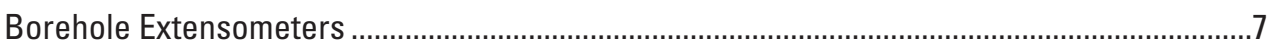

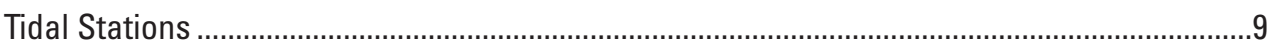

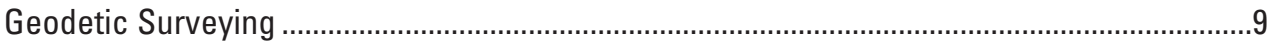

InSAR

Causes of Land Subsidence .................................................................................................... 10

Aquifer-System Compaction From Groundwater Withdrawals ............................................11

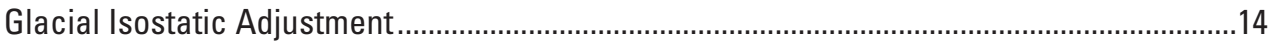

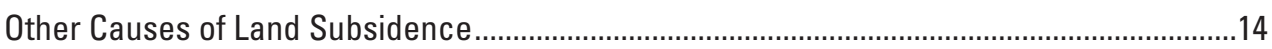

Rates of Land Subsidence and Sea-Level Rise in the Southern Chesapeake Bay Region.............15

Measured Rates of Land Subsidence ...............................................................................15

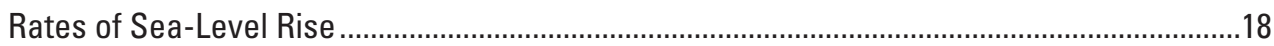

Links Between Groundwater Withdrawals and Land Subsidence ......................................19

What Resource Managers Should Know About Land Subsidence in the

Southern Chesapeake Bay Region........................................................................................20

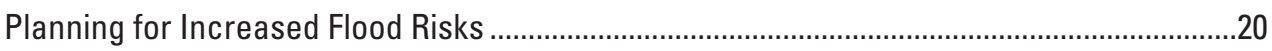

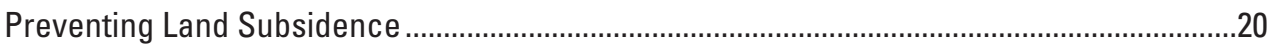

Information Needed to Understand Land Subsidence and Sea-Level Rise ...........................21

Need for Improved Understanding of Land Subsidence in the Region ..................................21

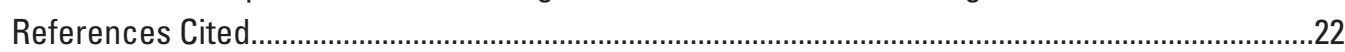

\section{Figures}

1. Photograph showing coastal flooding along the shore of the Elizabeth River in the Ghent neighborhood of Norfolk, Virginia, from a minor tide in February 2003 .................2

2. Map showing stations for monitoring land and sea elevations in the southern Chesapeake Bay region.................................................................................................

3. Diagram showing shoreline retreat caused by a combination of sea-level rise and land subsidence ..............................................................................................................

4. Photograph of Jamestown, Virginia, next to the James River showing the reconstructed colonial-era fort wall ..............................................................................

5. Photograph of downtown Franklin, Virginia, during flooding caused by Hurricane

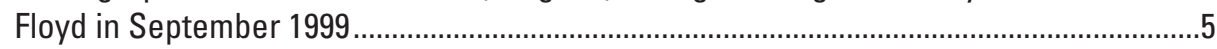

6. Diagram of forces and processes that influence marsh and wetland development. ......6

7. Photographs of the borehole extensometer in Franklin, Virginia ......................................7

8. Diagram of the borehole extensometer in Franklin, Virginia...........................................8

9. Map showing groundwater water-level decreases from 1900 to 2008 ...........................12

10. Diagram showing aquifer-system compaction caused by groundwater withdrawals...13 
11. Generalized hydrogeologic section illustrating layering in the Virginia Coastal Plain aquifer system from west to east.

12. Map showing land elevation change rates from 1940 through 1971 ..............................16

13. Graph showing aquifer-system compaction measured by borehole extensometers in Franklin, Virginia and in Suffolk, Virginia

14. Graph showing monthly mean sea levels at Sewells Point in Norfolk, Virginia, at National Oceanic and Atmospheric Administration station

15. Graph showing groundwater withdrawal rates from Virginia Coastal Plain aquifers from 1900 to 2008.

16. Graph showing water levels in the Potomac aquifer at U.S. Geological Survey (USGS) groundwater monitoring well in New Kent County, Virginia

\section{Tables}

1. Land subsidence monitoring methods

2. Relative sea-level rise at selected National Oceanic and Atmospheric Administration tidal stations in the southern Chesapeake Bay region

3. Observed sea-level rise and subsidence in the southern Chesapeake Bay region .......17

\section{Conversion Factors and Datum}

\begin{tabular}{lcl}
\hline \multicolumn{1}{c}{ Multiply } & \multicolumn{1}{c}{ By } & \multicolumn{1}{c}{ To obtain } \\
\hline & Length & \\
\hline millimeter $(\mathrm{mm})$ & 0.03937 & inch (in.) \\
meter $(\mathrm{m})$ & 3.281 & foot (ft) \\
kilometer $(\mathrm{km})$ & 0.6214 & mile $(\mathrm{mi})$ \\
\hline \multicolumn{2}{c}{ Area } & \\
\hline square kilometer $\left(\mathrm{km}^{2}\right)$ & 0.004047 & acre \\
\hline & Flow rate & \\
\hline millimeter per year $(\mathrm{mm} / \mathrm{yr})$ & 25.4 & inch per year $(\mathrm{in} / \mathrm{yr})$ \\
\hline
\end{tabular}

Vertical coordinate information is referenced to North American Vertical Datum of 1988 (NAVD 88).

Horizontal coordinate information is referenced to North American Datum of 1983 (NAD 83).

Elevation, as used in this report, refers to distance above the vertical datum.

\section{Abbreviations}

CORS Continuously Operating Reference Station

GPS Global Positioning System

InSAR interferometric synthetic aperture radar

NOAA National Oceanic and Atmospheric Administration

SAR synthetic aperture radar

USGS U.S. Geological Survey 


\title{
Land Subsidence and Relative Sea-Level Rise in the Southern Chesapeake Bay Region
}

\author{
By Jack Eggleston and Jason Pope
}

The southern Chesapeake Bay region is experiencing land subsidence and rising water levels due to global sea-level rise; land subsidence and rising water levels combine to cause relative sea-level rise. Land subsidence has been observed since the 1940s in the southern Chesapeake Bay region at rates of 1.1 to 4.8 millimeters per year ( $\mathrm{mm} / \mathrm{yr}$ ), and subsidence continues today.

This land subsidence helps explain why the region has the highest rates of sea-level rise on the Atlantic Coast of the United States. Data indicate that land subsidence has been responsible for more than half the relative sea-level rise measured in the region. Land subsidence increases the risk of flooding in low-lying areas, which in turn has important economic, environmental, and human health consequences for the heavily populated and ecologically important southern Chesapeake Bay region.

The aquifer system in the region has been compacted by extensive groundwater pumping in the region at rates of $1.5-$ to $3.7-\mathrm{mm} / \mathrm{yr}$; this compaction accounts for more than half of observed land subsidence in the region. Glacial isostatic adjustment, or the flexing of the Earth's crust in response to glacier formation and melting, also likely contributes to land subsidence in the region.

Aerial view of Little Creek and Joint Expeditionary Base Little Creek-Fort Story in Virginia Beach, Virginia. The Chesapeake Bay is seen in the upper right area of the photograph. Photograph by Steve Earley, The Virginian-Pilot, November 1998, used with permission. 


\section{Land subsidence makes coastal flooding more severe in the Hampton Roads area.}

The southern Chesapeake Bay region consists of the Chesapeake Bay and adjoining estuaries, the Virginia Coastal Plain to the west and south, and the Delmarva Peninsula (also called the Eastern Shore) to the east. Rivers draining to the southern Chesapeake Bay include the Elizabeth, James, Rappahannock, and York, as well as numerous smaller streams and tidal channels. Because of the low-lying topography, land and sea elevations are in a delicate balance (fig. 1). The relatively flat topography means that small decreases in land elevations or small increases in sea levels can increase flooding potential in urban and undeveloped areas.

Hampton Roads is the sole large urban center in the southern Chesapeake Bay region, consists of 13 communities, and has a population of 1.7 million people (fig. 2; U.S. Census Bureau, 2010). Hampton Roads is home to one of the largest ports on the east coast of the United States and many military bases, including Norfolk Naval Shipyard, the world's largest naval base. Many densely populated areas within Hampton Roads lie along the shores of tidal water bodies.

The southern Chesapeake Bay region also contains valuable natural and historical sites that are vulnerable to land subsidence and sea-level rise (Saunders and others, 2010). The Chesapeake Bay, as a whole, is the largest estuary in the United States and is home to hundreds of plant and animal species, including threatened and endangered species (Chesapeake Bay Program, 2011). The southern Chesapeake Bay region has more than a dozen wildlife refuges that protect important estuarine environments.

Land subsidence increases the rate of relative sea-level rise and helps explain why the southern Chesapeake Bay region has the highest rate of sea-level rise on the Atlantic Coast of the United States (Zervas, 2009). As communities in the region grapple with flooding problems and prepare for higher sea levels in the future, it is important to understand and potentially manage land subsidence.

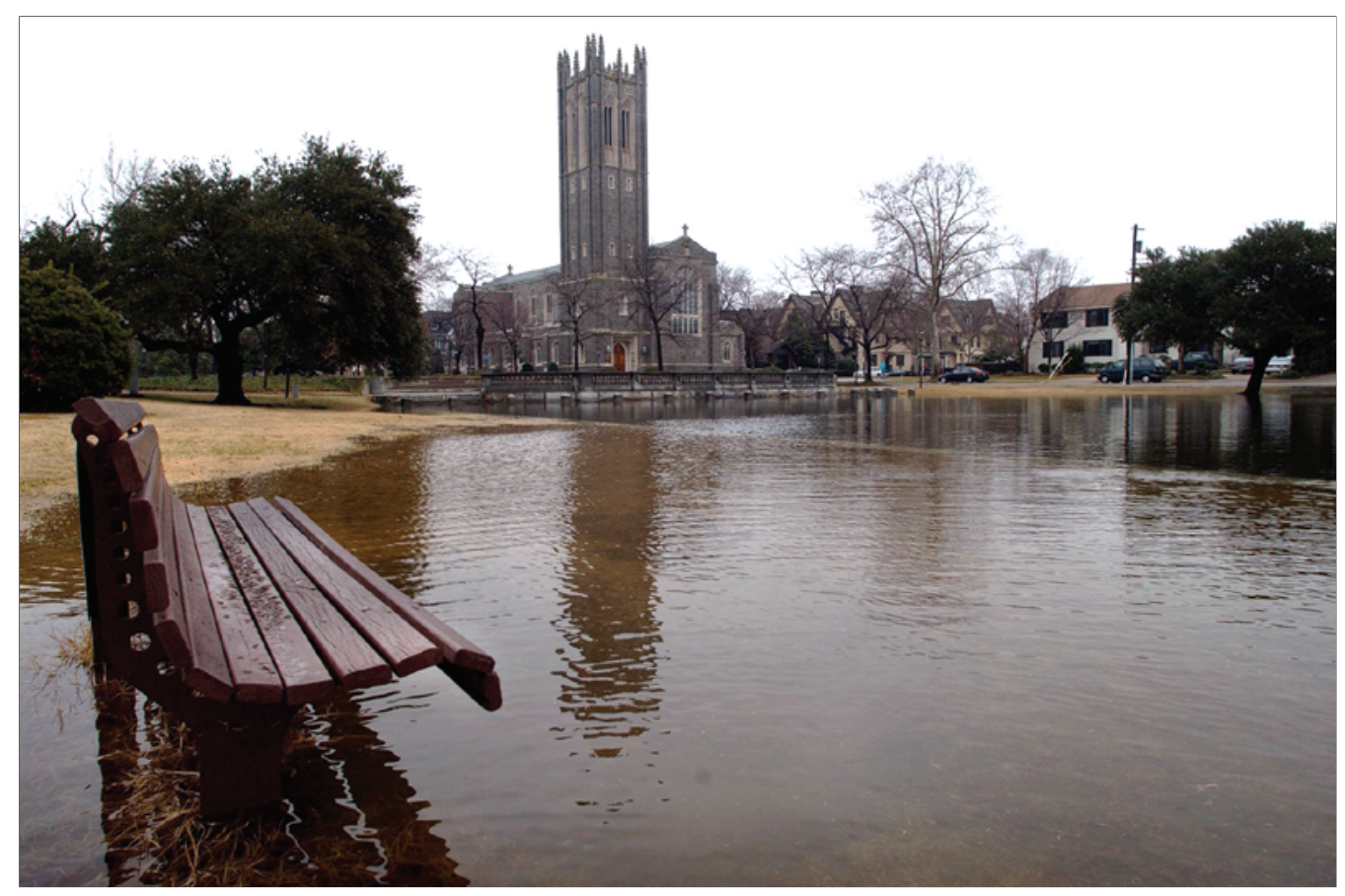

Figure 1. Coastal flooding along the shore of the Elizabeth River in the Ghent neighborhood of Norfolk, Virginia, from a minor tide in February 2003. Interaction between water and land in the southern Chesapeake Region affects its renowned estuaries and urban and military infrastructure. Slight increases in water levels or decreases in land-surface elevations can increase the risk of flooding in low-lying areas. Photograph by Vasna Wilson, courtesy of The Virginian-Pilot, used with permission. 


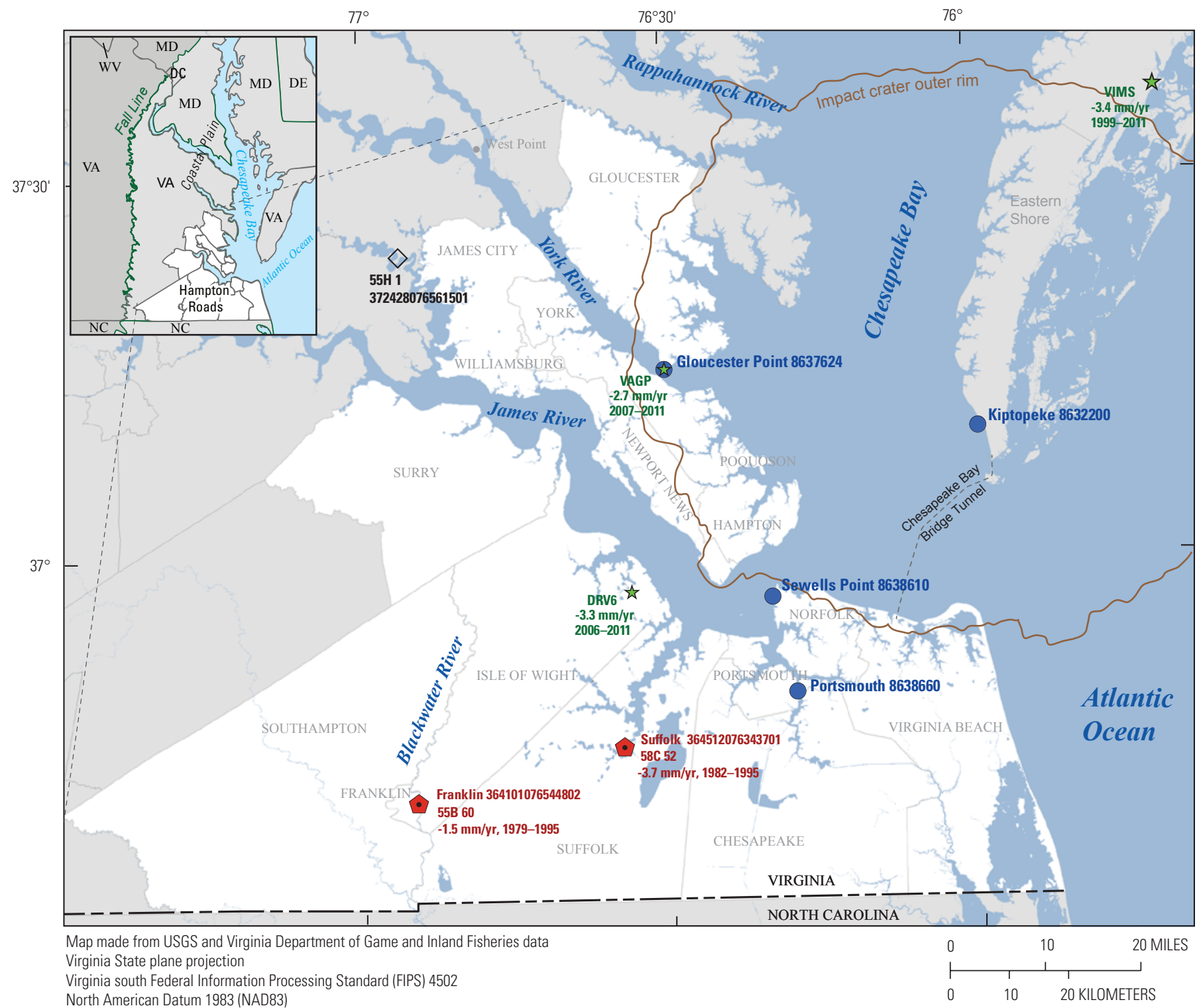

EXPLANATION

National Oceanic and Atmospheric Administration tidal station, location, and identification number (Zervas, 2009)

th Continuously Operating Reference Station (CORS), name, and rate of subsidence for years indicated (National Geodetic Survey, 2013)

U.S. Geological Survey (USGS) groundwater monitoring well, local name, and identification number

USGS extensometer station, location, number, local name, and rate of subsidence for years indicated (Pope and Burbey, 2004)

Figure 2. Stations for monitoring land and sea elevations in the southern Chesapeake Bay region. The Atlantic Coastal Plain is shown in light gray shading. Hampton Roads Planning District Commission (HRPDC) communities within the Atlantic Coastal Plain are shown in white shading. mm/yr, millimeters per year; NOAA, National Oceanic and Atmospheric Administration; USGS, U.S. Geological Survey; VA, Virginia. 
Land subsidence is the sinking or lowering of the land surface.

\section{Description of Land Subsidence}

Land subsidence is the sinking or lowering of the land surface. Most land subsidence in the United States is caused by human activities (Galloway and others, 1999). Two wellstudied cases of land subsidence are in the Houston-Galveston, Texas, area and the Santa Clara Valley, California. Land sank by as much as 3 meters $(\mathrm{m})$ over 50 years because of intensive groundwater withdrawals in the two areas, as well as petroleum extraction in Texas, resulting in increased coastal flooding (Poland, 1984; Galloway and others, 1999; Bawden and others, 2012). Regional authorities were established in the two areas to manage water use and land subsidence. The regional authorities set up monitoring networks and enlisted scientists to study the problem. Ultimately, the communities adopted new water-management practices to prevent land subsidence, including relocating groundwater withdrawals away from the coast, substituting surface water for groundwater supplies, and increasing aquifer recharge. In the Santa Clara Valley, subsidence has mostly been stopped and, in the Houston-Galveston area, subsidence has been slowed, particularly along vulnerable shorelines (Bawden and others, 2012).

Rates and locations of land subsidence change over time so accurate measurements and predictive tools are needed to improve understanding of land subsidence. Although rates of land subsidence are not as high on the Atlantic Coast as they have been in the HoustonGalveston area or the Santa Clara Valley, land subsidence is important because of the low-lying topography and susceptibility to sea-level rise in the southern Chesapeake Bay region.

\section{Why Land Subsidence is a Concern in the Southern Chesapeake Bay Region}

Land subsidence can increase flooding, alter wetland and coastal ecosystems, and damage infrastructure and historical sites. Because land subsidence contributes to relative sea-level rise in the region, it is important for regional planners to understand why, where, and how fast it is occurring, now and in the future.

\section{Land Subsidence Contributes to Relative Sea-Level Rise}

Land subsidence contributes to the relative sea-level rise that has been measured in the Chesapeake Bay (fig. 2). However, tidal-station measurements of sea levels do not distinguish between water that is rising and land that is sinking - the combined elevation changes are termed relative sea-level rise. Global sea-level rise and land subsidence increase the risk of coastal flooding and contribute to shoreline retreat (fig. 3).

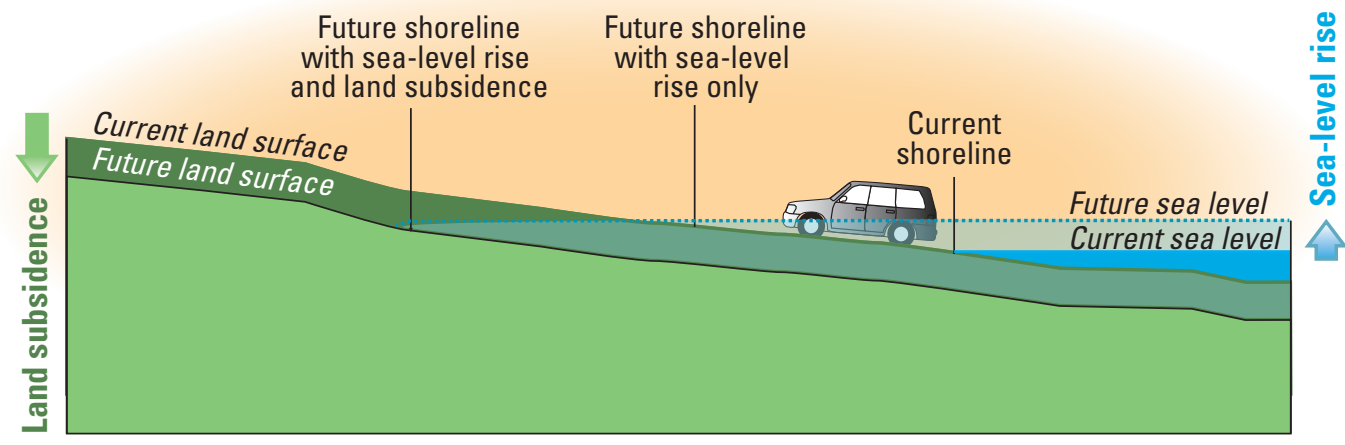

Figure 3. Shoreline retreat caused by a combination of sea-level rise and land subsidence. 


\section{Land Subsidence Increases Flood Risk}

As relative sea levels rise, shorelines retreat and the magnitude and frequency of near-shore coastal flooding increase. Although land subsidence can be slow, its effects accumulate over time. This has been an expensive problem in the Houston-Galveston area and the Santa Clara Valley (Galloway and others, 1999) and likely contributes to current flooding problems in the southern Chesapeake Bay region. Analysis by McFarlane (2012) found that between 59,000 and 176,000 residents living near the shores of the southern Chesapeake Bay could be either permanently inundated or regularly flooded by 2100 . This estimate was based on 2010 census data, using the spring high-tide as a reference elevation and assuming a 1-m relative sea-level rise. Damage to personal property was estimated to be $\$ 9$ billion to $\$ 26$ billion, and 120,000 acres of ecologically valuable land could be inundated or regularly flooded, under these same assumptions. Historic and cultural resources are also vulnerable to increased flooding from relative sea-level rise in the southern Chesapeake Bay, particularly at shoreline sites near tidal water, such as the 17 th century historic Jamestown site (fig. 4).

Land subsidence can also increase flooding in areas away from the coast. Low-lying areas, such as the Blackwater River Basin (fig. 2), can be subject to increased flooding as the land sinks. Locations along the Blackwater River in the city of Franklin and the counties of Isle of Wight and Southampton have experienced large floods in recent years (fig. 5; Federal Emergency Management Agency, 2002). Land subsidence may be altering the topographic gradient that drives the flow of the river and possibly contributing to the flooding.

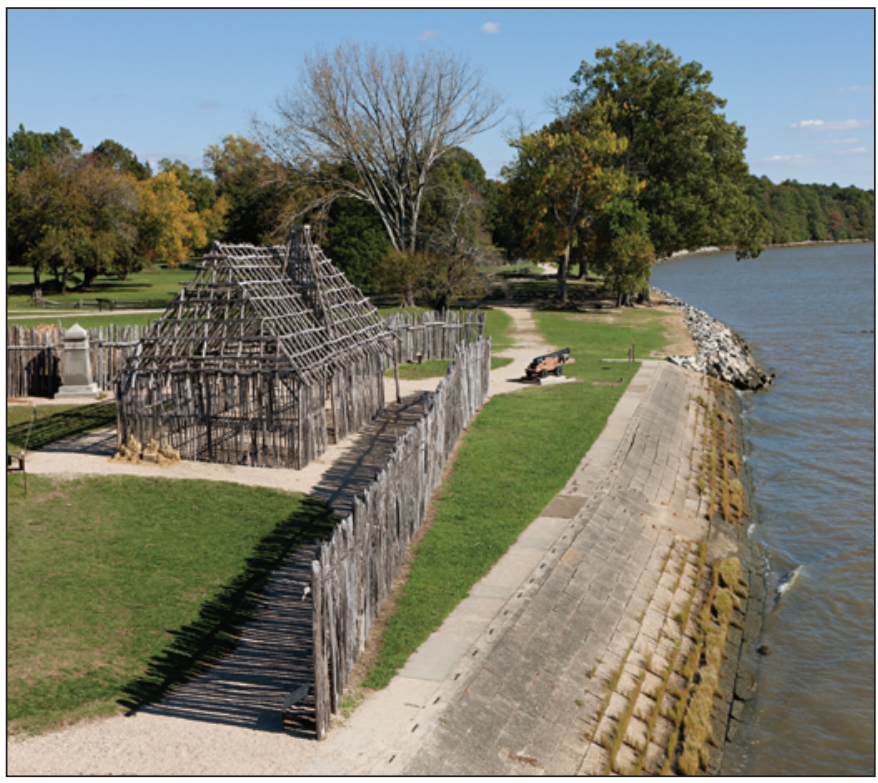

Figure 4. Jamestown, Virginia, next to the James River showing the reconstructed colonial-era fort wall. Photograph courtesy of The Colonial Williamsburg Foundation, used with permission.

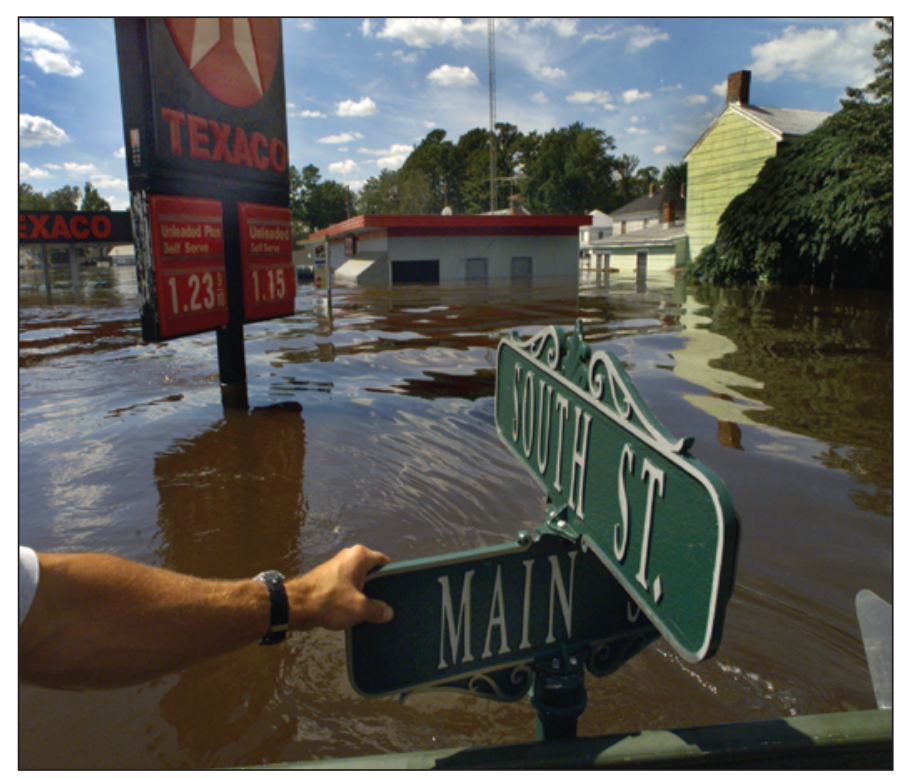

Figure 5. Downtown Franklin, Virginia, during flooding caused by Hurricane Floyd in September 1999. Photograph by John H. Sheally II, courtesy of The Virginian-Pilot, used with permission. 


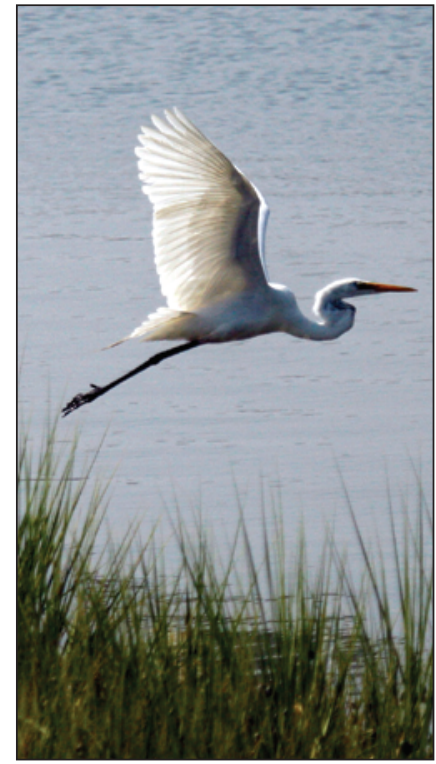

A great egret takes to the air along the Lynnhaven River in Virginia Beach, Virginia, at a conservation area that features oyster beds, wetlands, and a maritime forest. Photograph by L. Todd Spencer, The Virginian-Pilot, July 2010, used with permission.

Rates of land subsidence vary with location and change over time.

\section{Land Subsidence Can Damage Wetland and Coastal Marsh Ecosystems}

Wetland and marsh ecosystems in low-lying coastal areas are very sensitive to small changes in elevation (Cahoon and others, 2009). Salt marshes, which are widespread in the southern Chesapeake Bay region, are dependent on tidal dynamics for their existence. Small changes in either land or sea elevations can alter sediment deposition, organic production and plant growth, and the balance between fresh water and seawater (fig. 6; Morris and others, 2002).

Shoreline environments also are affected by land subsidence. When land subsides, it subjects shorelines to increased wave action, increasing erosion and washover. This type of damage is happening in the Chesapeake Bay because of relative sea-level rise (Erwin and others, 2011; Kirwan and Guntenspergen, 2012; Kirwan and others, 2012). Major changes in the coastal and marine ecosystems of the southern Chesapeake Bay are expected to be caused by relative sea-level rise (Gutierrez and others, 2009); these changes will likely be more severe if land subsidence continues.

\section{Land Subsidence Can Damage Infrastructure}

Infrastructure such as buildings, bridges, pipes, and canals can be damaged from relative groundwater rise or from differential settling in areas with high subsidence gradients (Galloway and others, 1999). As land sinks and sea level continues to rise, groundwater levels rise towards the land surface in coastal areas, which can cause problems for subterranean structures, septic fields, buried pipes and cables, and infrastructure not designed for elevated groundwater levels. Storm and wastewater sewers in urban areas are vulnerable because land subsidence can alter the topographic gradient driving the flow through the sewers, causing increased flooding and more frequent sewage discharge from combined sewer overflows.

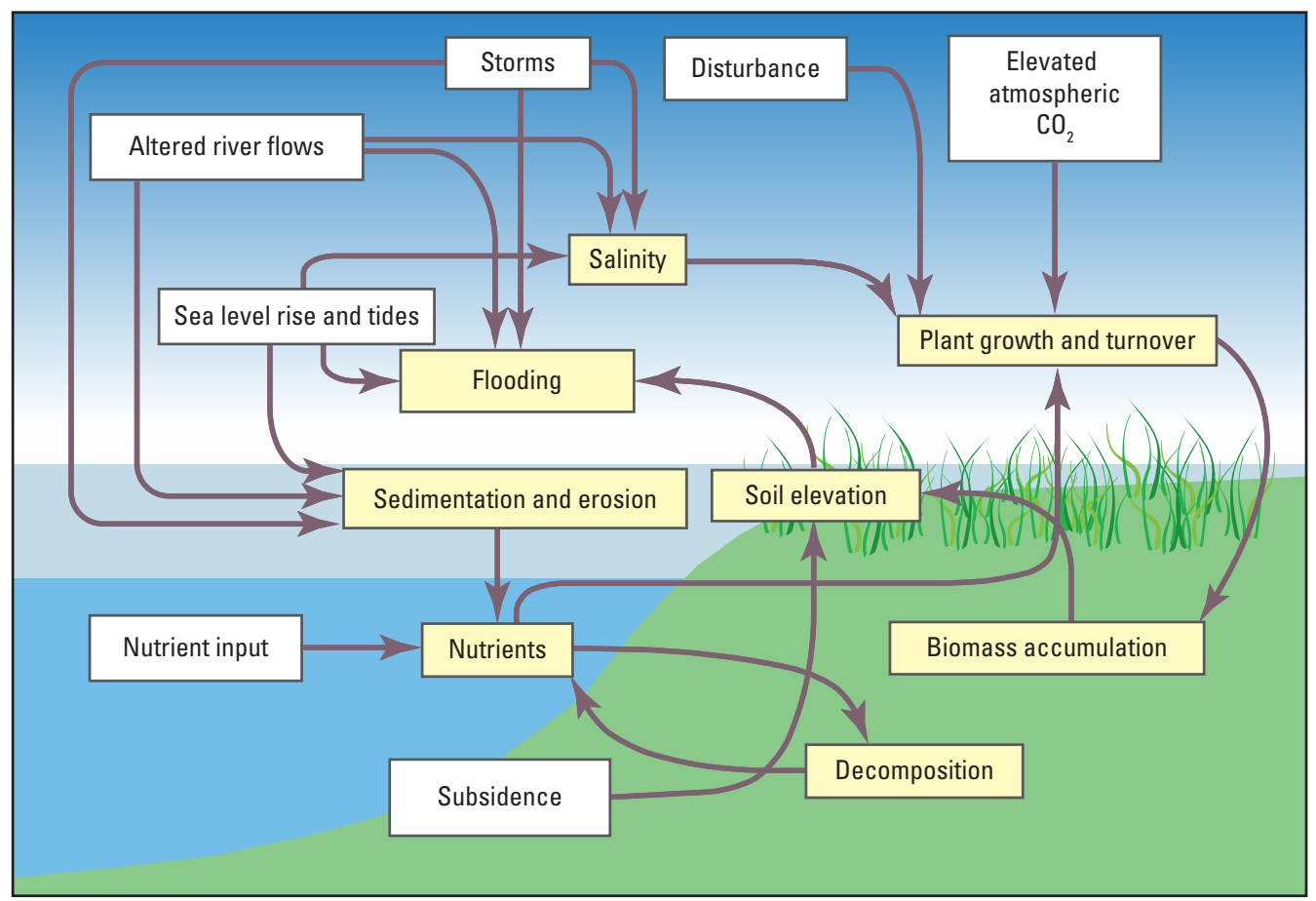

Figure 6. Forces and processes that influence marsh and wetland development. Environmental drivers (white boxes) and accretionary processes (yellow boxes) influence vertical marsh and wetland development. Modified from Cahoon and others (2009). $\mathrm{CO}_{2}$, carbon dioxide. 


\section{How Land Subsidence is Measured}

There are several reliable and accurate techniques for measuring land subsidence.

Multiple monitoring techniques are often used together to understand different aspects of land subsidence (table 1). Rates and locations of land subsidence change over time, so repeat measurements at multiple locations are often needed to improve understanding of the complex phenomenon and guide computer models that forecast future subsidence. Extensometers measure changes in aquifer-system thickness, whereas other methods measure land surface elevation, from which subsidence is calculated by subtracting measurements over time.

\section{Borehole Extensometers}

A borehole extensometer measures compaction or expansion of an aquifer system independently of other vertical movements, such as crustal and tectonic motions (Galloway and others, 1999). An extensometer measures changes in aquifer-system thickness by recording changes in the distance between two points in a well (fig. 7). Usually the two measurement points are established at the top and bottom of a well to measure total aquifer-system compaction between the land surface and the bottom of the aquifer system (fig. 8).

Alternatively, specific intervals within a well can be measured, for example, to measure compaction of just one aquifer within a layered aquifer system. Extensometer measurements are often combined with surface monitoring techniques to determine the portion of total land subsidence attributable to aquifer-system compaction (Poland, 1984).

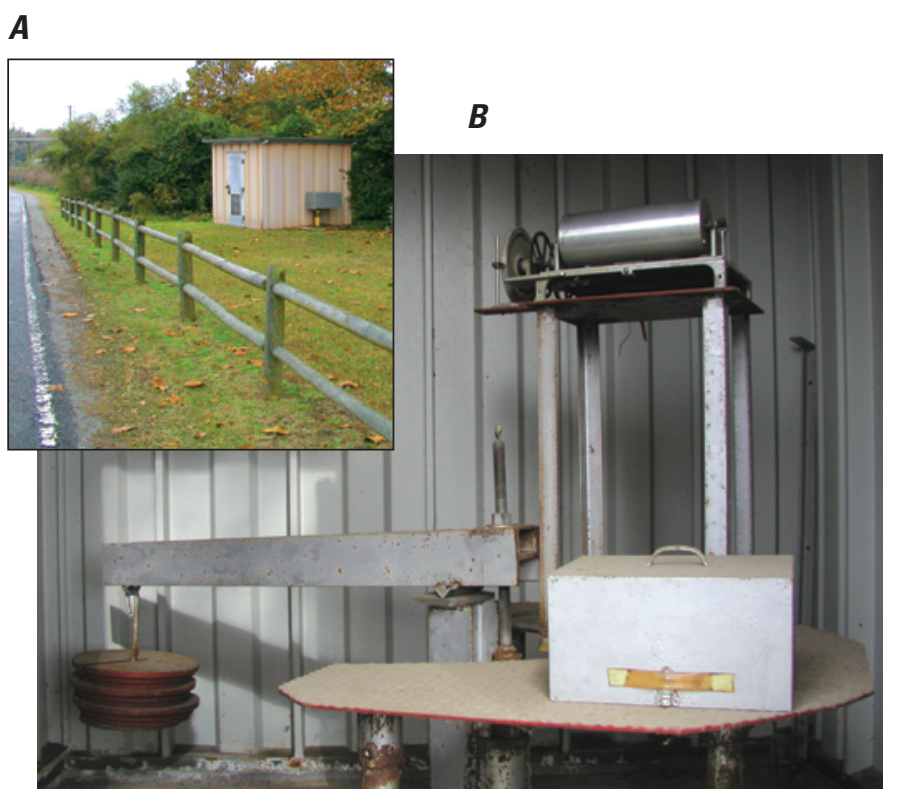

Figure 7. The borehole extensometer in Franklin, Virginia. $A$, Survey station house; photograph by Jason Pope, U.S. Geological Survey ; $B$, recording equipment; photograph by Chuck Heywood, U.S. Geological Survey.

Table 1. Land subsidence monitoring methods.

[GPS, Global Positioning System; InSAR, interferometric synthetic aperture radar]

\begin{tabular}{|c|c|c|c|c|}
\hline Method & Type of data & $\begin{array}{l}\text { Measures aquifer- } \\
\text { system compaction } \\
\text { independently }\end{array}$ & Spatial coverage & Temporal detail \\
\hline Borehole extensometer & $\begin{array}{l}\text { Aquifer-system thickness at one location, } \\
\text { continuous record }\end{array}$ & Yes & Low & High \\
\hline Tidal station & $\begin{array}{l}\text { Sea elevation at one location, continuous } \\
\text { record }\end{array}$ & No & Low & High \\
\hline Geodetic surveying & $\begin{array}{l}\text { Land elevations at one or several locations, } \\
\text { multiple times or continuous record }\end{array}$ & No & Low to moderate & Low to high \\
\hline Remote sensing (InSAR) & $\begin{array}{l}\text { Land elevations over a wide area, at } \\
\text { multiple times }\end{array}$ & No & High & Moderate \\
\hline
\end{tabular}




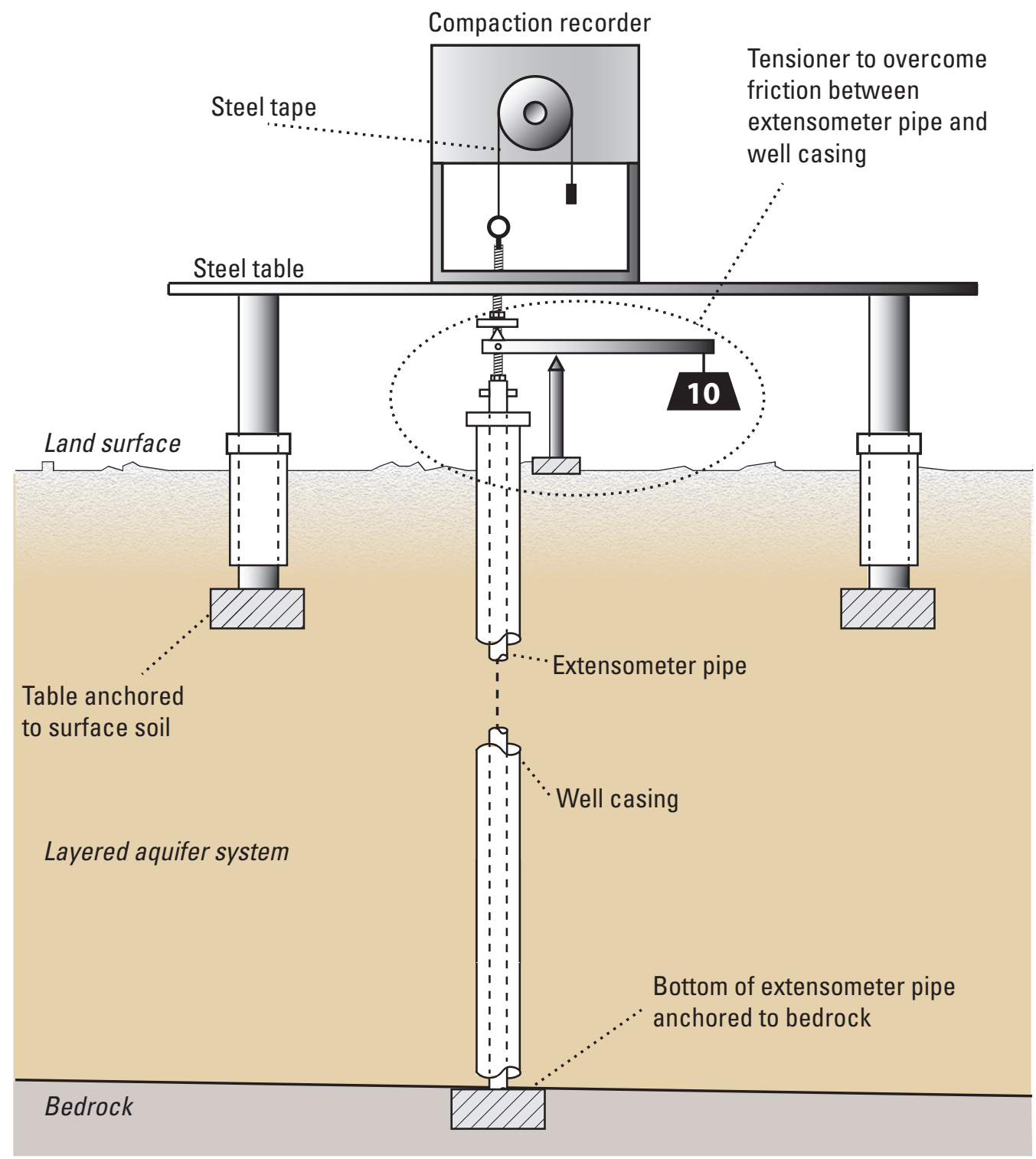

Figure 8. The borehole extensometer in Franklin, Virginia. Modified from Pope (2002). 


\section{Tidal Stations}

A tidal station measures sea elevation at one location. To determine long-term trends, sea-level measurements are averaged over time to remove the effect of waves, tides, and other short-term fluctuations. In the southern Chesapeake Bay, tidal stations have been in operation for many decades (fig. 2; table 2). Tidal station data are valuable because they indicate relative sea-level rise.

Table 2. Relative sea-level rise at selected National Oceanic and Atmospheric Administration tidal stations in the southern Chesapeake Bay region.

[Data are from Zervas (2009). Locations of monitoring stations are shown in figure 2. CI, confidence interval; mm, millimeters; $\mathrm{mm} / \mathrm{yr}$, millimeters per year; $\%$, percent]

\begin{tabular}{|c|c|c|c|c|}
\hline \multirow[b]{2}{*}{ ID } & \multirow[b]{2}{*}{ Site name } & \multirow[b]{2}{*}{ Period } & \multicolumn{2}{|c|}{ Rate of relative sea-level rise } \\
\hline & & & $\begin{array}{c}\text { Measured, } \\
(\mathrm{mm} / \mathrm{yr})\end{array}$ & $95 \% \mathrm{Cl}$ \\
\hline 8632200 & Kiptopeke, Virginia & $1951-2006$ & 3.5 & \pm 0.42 \\
\hline 8637624 & Gloucester Point, Virginia & $1950-2006$ & 3.8 & \pm 0.47 \\
\hline 8638610 & Sewells Point, Virginia & $1927-2006$ & 4.4 & \pm 0.27 \\
\hline \multirow[t]{2}{*}{8638660} & Portsmouth, Virginia & $1935-2006$ & 3.8 & \pm 0.45 \\
\hline & Average & & 3.9 & \pm 0.40 \\
\hline
\end{tabular}

\section{Geodetic Surveying}

Geodetic surveying is the measurement of land surface coordinates. Geodetic surveying is most commonly performed either with traditional optical leveling equipment or with Global Positioning System (GPS) technology that reads signals from satellites to obtain very detailed location and time information. Where historical geodetic survey records are available, as they are for the southern Chesapeake Bay region, geodetic surveying can be useful to determine cumulative land subsidence over many decades. Benchmark stations are established and, for as long as they remain undisturbed, can be surveyed multiple times to determine elevation changes between surveys.

The National Geodetic Survey manages the Continuously Operating Reference Station (CORS) network, a network of long-term GPS stations throughout the United States that includes stations in the southern Chesapeake Bay region (fig. 2). Each CORS station continuously records three-dimensional position data (north-south, east-west, and up-down), allowing rates of change to be calculated over time (Snay and Soler, 2008). A CORS station records ground position at one site and is designed to operate for many years.

In addition to stationary GPS sites such as the CORS stations, portable GPS receivers can be used to expand spatial coverage. In the Houston-Galveston area, GPS receivers mounted on trailers have been used to collect data at up to four different sites each month (Galloway and others, 1999; Bawden and others, 2012). The portable GPS approach had acceptable subcentimeter accuracy, gave greater spatial coverage than stationary GPS would have, and had a lower cost than interferometric synthetic aperture radar (InSAR) technology.

Tidal station data are valuable because they indicate relative sea-level rise. 


\section{InSAR}

The remote sensing technique InSAR has been used to investigate surface deforma-

InSAR is a remote sensing technique used to investigate land surface deformation resulting from land subsidence. tion resulting from land subsidence (Galloway and Hoffman, 2007). With InSAR, as little as 5 millimeters $(\mathrm{mm})$ of elevation change can be measured over hundreds or thousands of square kilometers with a horizontal spatial resolution down to $20 \mathrm{~m}$ (Pritchard, 2006). Maps called interferograms that show land-surface elevation changes are produced by combining two synthetic aperture radar (SAR) images acquired by multiple satellite or airborne passes over the same area at different times. InSAR analysis has the advantage of measuring subsidence over a large area, whereas traditional geodetic leveling and GPS surveying are performed at only one or a handful of locations during a survey (Sneed and others, 2002; Stork and Sneed, 2002).

There are potential limitations to using InSAR in the southern Chesapeake Bay region. Subsidence rates determined by InSAR might have errors that are larger than the subsidence rates observed in the region ( 1.1 to $4.8 \mathrm{~mm} / \mathrm{yr}$ ). The region's dense vegetation and high humidity would create spurious radar signals, require the use of persistent scatter techniques, and result in lower measurement resolution than is found in more arid regions (Raucoules and others, 2009). In addition, available satellite data cover only a relatively short time span. The best available synthetic aperture radar (SAR) satellite data for the southern Chesapeake Bay region cover from 1992 to 2000, so the time of accumulated subsidence determined from these data would be no more than 8 years. Despite these limitations, InSAR could be used to identify hotspot areas of subsidence. Such mapping could be useful for identifying unexpected areas of subsidence, focusing attention on important areas, and picking locations for other ground-based subsidence monitoring techniques (Michelle Sneed, U.S. Geological Survey, written commun., 2012).

\section{Causes of Land Subsidence}

It is important to know the causes of land subsidence so that it can be more effectively managed. Most land subsidence in the United States is caused by human activities (Galloway and others, 1999), with groundwater withdrawals responsible for about 80 percent of land subsidence in the United States. Causes of subsidence that are most relevant to the southern Chesapeake Bay region include aquifer-system compaction caused by groundwater withdrawals and glacial isostatic adjustment.

Location of maximum subsidence in United States identified by research efforts of Joseph Poland (pictured) - San Joaquin Valley southwest of Mendota, California. Land subsidence in this area was caused by excessive groundwater pumping. Signs on pole show approximate altitude of land surface in 1925, 1955, and 1977. Photograph from Galloway and others (1999), USGS.

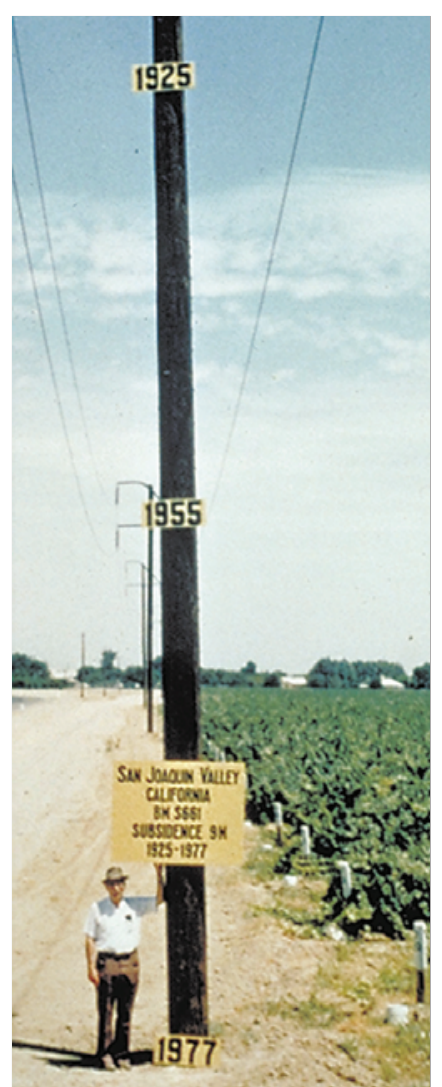




\section{Aquifer-System Compaction From Groundwater Withdrawals}

When groundwater is pumped from an aquifer system, pressure decreases. The pressure change is reflected by water levels in wells, with water levels decreasing as aquifer-system pressure decreases. This is happening over most of the southern Chesapeake Bay region, with the greatest water-level decreases seen near the pumping centers of Franklin and West Point, Virginia (fig. 9). As water levels decrease, the aquifer system compacts, causing the land surface above to subside (fig. 10). Water levels have decreased over the entire Virginia Coastal Plain in the Potomac aquifer, which is the deepest and thickest aquifer in the southern Chesapeake Bay region and supplies about 75 percent of groundwater withdrawn from the Virginia Coastal Plain aquifer system (Heywood and Pope, 2009).

The amount of aquifer-system compaction is determined by three factors: water-level decline, sediment compressibility, and sediment thickness. If any of these three factors increase in magnitude, then the amount of aquifer-system compaction and land subsidence increases. Because all three of these factors vary spatially across the southern Chesapeake Bay region, rates of land subsidence caused by aquifer-system compaction also vary spatially across the region.

The Virginia Coastal Plain aquifer system consists of many stacked layers of sand and clay (fig. 11). Although groundwater is withdrawn primarily from the aquifers (sandy layers), most compaction occurs in confining units and clay lenses, the relatively impermeable layers sandwiched between and within the aquifers (Pope and Burbey, 2004). The compression of clay layers is mostly nonrecoverable, meaning that, if groundwater levels later recover and increase, then the aquifer system does not expand to its previous volume and the land surface does not rise to its previous elevations (Pope, 2002). Konikow and Neuzil (2007) estimated that 95 percent of the water removed from storage in the Virginia Coastal Plain aquifer system between 1891 and 1980 was derived from the confining layers.

The timing of aquifer-system compaction is also important. Compaction can continue for many years or decades after groundwater levels drop. When groundwater is pumped from an aquifer, pressure decreases in the aquifer. The pressure decrease then slowly propagates into clay layers that are adjacent to or within the aquifer. As long as pressure continues to decrease in the clay layers, compaction continues.

The layered sediments of the Virginia Coastal Plain aquifer system range in grain size from very fine (silts and clays) to coarse (sand and shell fragments) (McFarland and Bruce, 2006). Based on the hydrogeologic framework of McFarland and Bruce (2006) and Heywood and Pope (2009), confining layers outside the meteor impact crater occupy about 16 percent of the total aquifer-system thickness, an average of $100 \mathrm{~m}$ out of the total average thickness of $619 \mathrm{~m}$. These confining layers have high specific storage (compressibility) estimated to be 0.00015 per meter (Pope and Burbey, 2004). Clay layers overlying and within the Potomac aquifer are compressing as aquifer pressure decreases migrate vertically and laterally from pumping wells. 


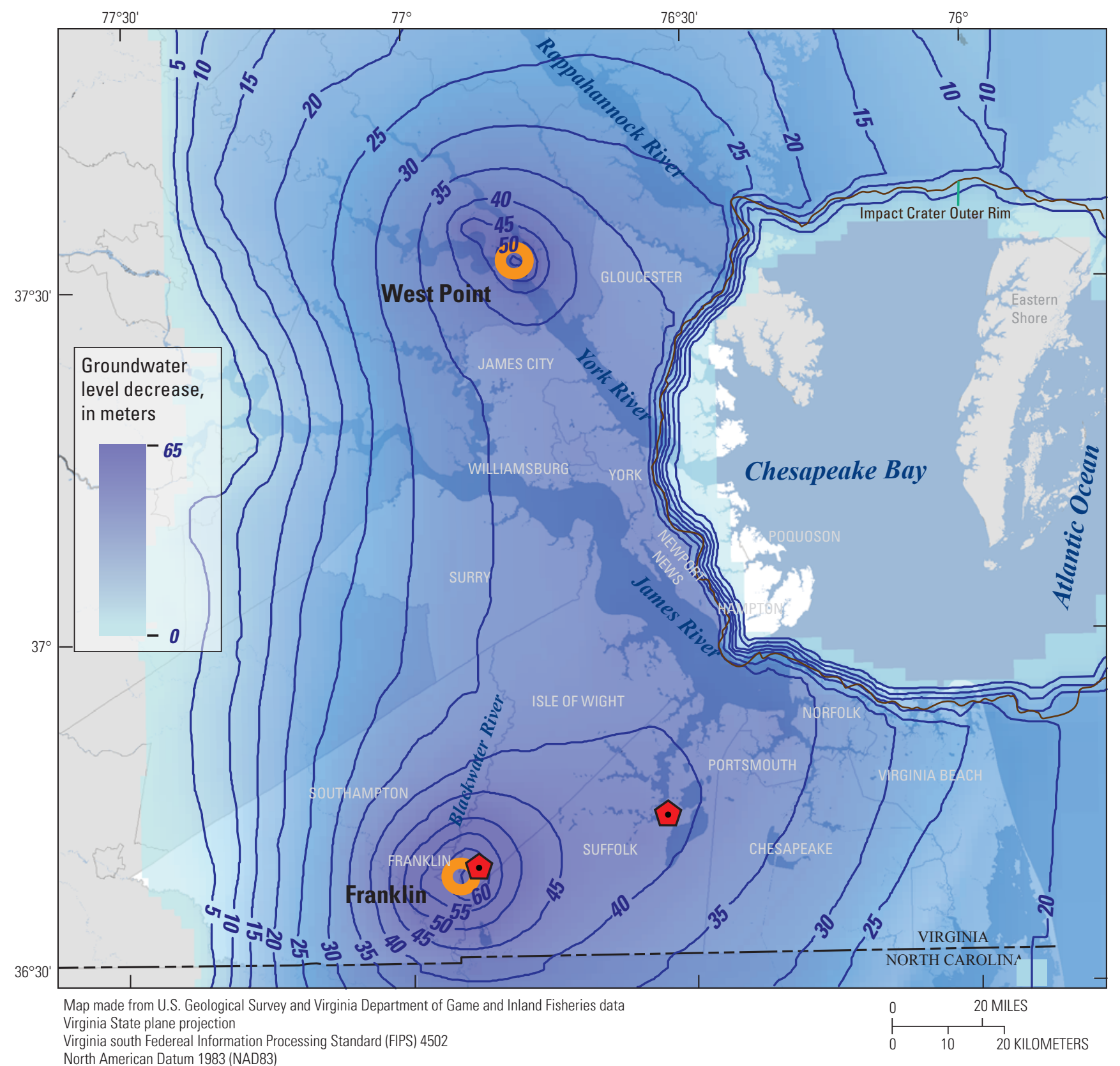

EXPLANATION

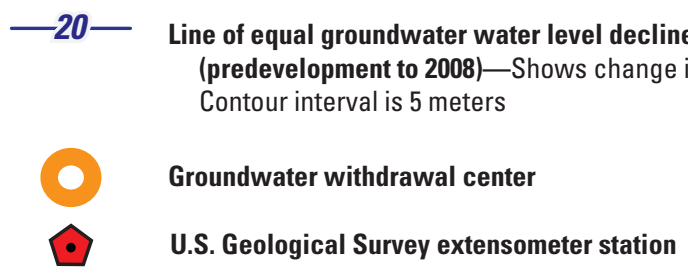

Figure 9. Groundwater water-level decreases from 1900 to 2008. Modified from Heywood and Pope (2009). 
A. Before pumping

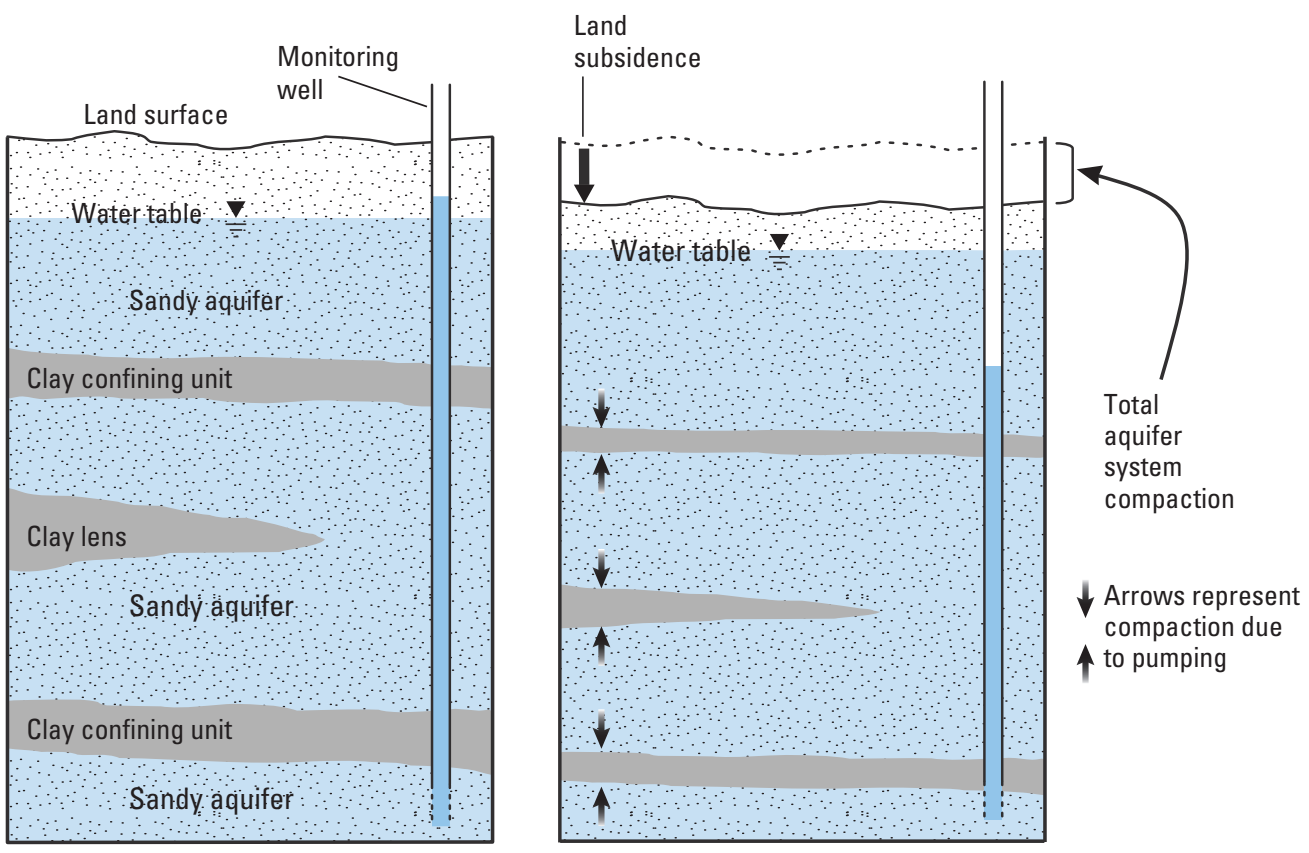

Figure 10. Aquifer-system compaction caused by groundwater withdrawals $A$, before and $B$, after pumping. Modified from Galloway and others (1999).

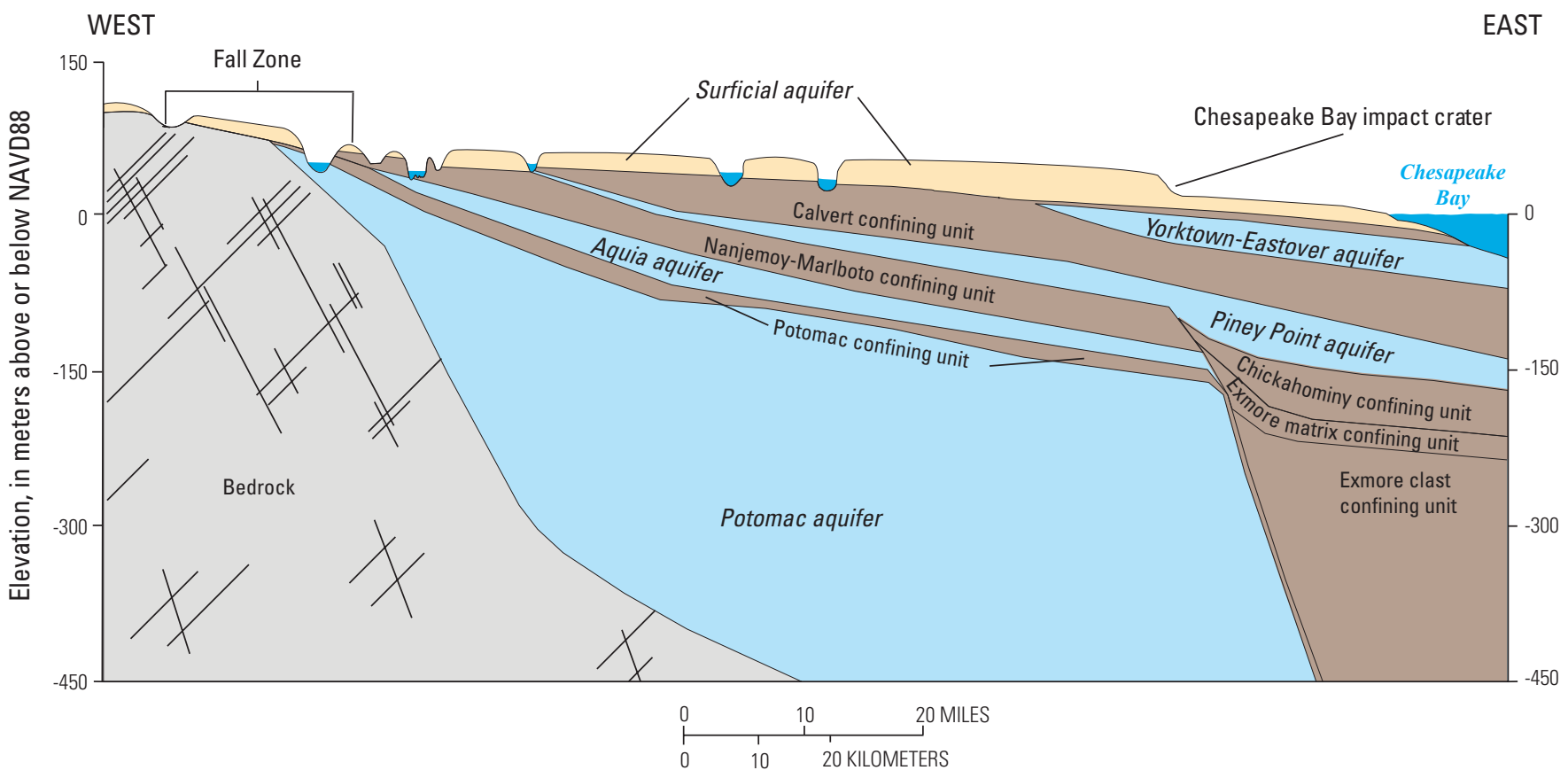

VERTICAL SCALE GREATLY EXAGGERATED

Figure 11. Section illustrating layering in the Virginia Coastal Plain aquifer system from west to east. Elevation relative to North American Vertical Datum of 1988 (NAVD88). Modified from McFarland and Bruce (2006). 


\section{Glacial Isostatic Adjustment}

Crystalline bedrock underlies the layered sediments of the Virginia Coastal Plain aquifer system. Bedrock is not solid and unyielding but actually flexes and moves in response to stress. Bedrock in the mid-Atlantic region is moving slowly downward in response to melting of the Laurentide ice sheet that covered Canada and the northern United States during the last ice age (Sella and others, 2007; Boon and others, 2010). When the ice sheet still existed, the weight of the ice pushed the underlying Earth's crust downward and, in response, areas away from the ice sheet were forced upward (called glacial forebulge). The southern Chesapeake Bay region is in the glacial forebulge area and was forced upward by the Laurentide ice sheet. The ice sheet started melting about 18,000 years ago and took many thousands of years to disappear entirely. As the ice melted and its weight was removed, glacial forebulge areas, which previously had been forced upward, began sinking and continue to sink today. This movement of the Earth's crust in response to ice loading or melting is called glacial isostatic adjustment. Data from GPS measurements and carbon dating of marsh sediments indicate that regional land subsidence in response to glacial isostatic adjustment in the southern Chesapeake Bay region may have a current rate of about $1 \mathrm{~mm} / \mathrm{yr}$ (Engelhart and others, 2009; Engelhart and Horton, 2012). This downward velocity rate is uncertain and probably not uniform across the region.

\section{Other Causes of Land Subsidence}

There are other causes of land subsidence, but there is currently little or no evidence that these other causes are important to regional subsidence processes in the southern Chesapeake Bay region. However, they are mentioned here and may warrant further study.

Bedrock dissolution is important in parts of the United States with evaporite (for example gypsum) or carbonate (for example limestone) rocks, but is unlikely to be contributing to land subsidence in the southern Chesapeake Bay region where bedrock is mostly crystalline (McFarland and Bruce, 2006).

Drainage and degradation of organic soils is a common cause of land subsidence in some parts of the United States (Galloway and others, 1999). Numerous marshes have been drained in the southern Chesapeake Bay region during the past few centuries to control mosquito populations or to create new land for agriculture and development. However, drained organic soils are not prevalent at the monitoring sites shown in figure 2 and, although degradation of organic soils may contribute locally to subsidence in some areas, it is not likely to be contributing to regional land subsidence.

Settling of fill and disturbed soils can cause land to sink. This may be happening in local areas where construction has disturbed soils, marshes have been filled in, or islands have been constructed, such as the islands constructed for the Chesapeake Bay Bridge Tunnel. However, settling of fill and disturbed soils cannot explain the subsidence observed across the southern Chesapeake Bay region.

Volcanic disturbances and tectonic motion related to continental crust movements are thought to have negligible contribution to land elevation changes along the Atlantic Coast of the United States because there are no volcanoes or tectonic plate margins in the region (Engelhart and others, 2009).

Settling of impact crater sediments associated with the Chesapeake Bay meteor crater (figs. 9 and 11) is an unlikely cause of current land subsidence in the region because the meteor 
struck about 35 million years ago (Powars and Bruce, 1999). The passage of time since the meteor impact has been so great that, even if it was conservatively assumed that subsidence rates had stayed constant during the past 1 million years rather than decreasing, a rate of $1 \mathrm{~mm} / \mathrm{yr}$ would equate to 1 kilometer of subsidence, which is not compatible with our current understanding of regional geology (McFarland and Bruce, 2006). Measured subsidence rates also indicate that the crater has the indirect effect of reducing modern-day subsidence caused by aquifer-system compaction, because the low-permeability sediments associated with the impact crater (Heywood and Pope, 2009) reduce groundwater level decreases within the rim of the crater (fig. 9).

\section{Rates of Land Subsidence and Sea-Level Rise in the Southern Chesapeake Bay Region}

Land subsidence has been known and observed in the southern Chesapeake Bay region for many decades and is a factor that should be considered by urban planners and natural resource managers. Some aspects of the subsidence problem, such as a full understanding of causes, spatial variability, and historical and future subsidence rates over time, would benefit from additional research.

\section{Measured Rates of Land Subsidence}

Land subsidence in the southern Chesapeake Bay region was first documented by Holdahl and Morrison (1974), who reported results of geodetic surveys completed between 1940 and 1971 and found land surfaces across the region were sinking at an average rate of $2.8 \mathrm{~mm} / \mathrm{yr}$ with rates ranging from 1.1 to $4.8 \mathrm{~mm} / \mathrm{yr}$ (fig. 12; table 3). The two areas where subsidence rates were fastest roughly coincide with groundwater pumping centers at Franklin and West Point. Measurements of land subsidence are currently (2013) made at CORS stations in the region. The National Geodetic Survey has computed velocities for three of these stations (fig. 2) between 2006 and 2011 and found an average subsidence rate of $3.1 \mathrm{~mm} / \mathrm{yr}$ (table 3; Snay and Soler, 2008; National Geodetic Survey, 2013).

Aquifer-system compaction was measured with extensometers at two locations in the region, at Franklin from 1979 to 1995 and at Suffolk from 1982 to 1995 (figs. 2 and 13; Pope and Burbey, 2004). The extensometers showed $24.2 \mathrm{~mm}$ of total compaction at Franklin from 1979 through $1995(1.5 \mathrm{~mm} / \mathrm{yr})$ and $50.2 \mathrm{~mm}$ of total compaction at Suffolk from 1982 through 1995 (3.7 mm/yr). Rates of compaction were correlated to groundwater-level decreases and to the aggregate thickness of compressible sediments at each location. The total thickness of compressible fine-grained sediments is $130.8 \mathrm{~m}$ at Suffolk and $62.7 \mathrm{~m}$ at Franklin. Water levels in the Potomac aquifer during the period of compaction measurement decreased more at Suffolk than at Franklin, about $5 \mathrm{~m}$ versus about $2 \mathrm{~m}$. Aquifer-system compaction has not been measured at any other locations in the southern Chesapeake Bay region but it likely affects most of the region because large water-level decreases in the aquifer system are widespread (fig. 9).

\section{Land subsidence in the} Hampton Roads area of the southern Chesapeake Bay region has averaged about $3 \mathrm{~mm} / \mathrm{yr}$ since 1940. Measured rates range from 1.1 to $4.8 \mathrm{~mm} / \mathrm{yr}$. 


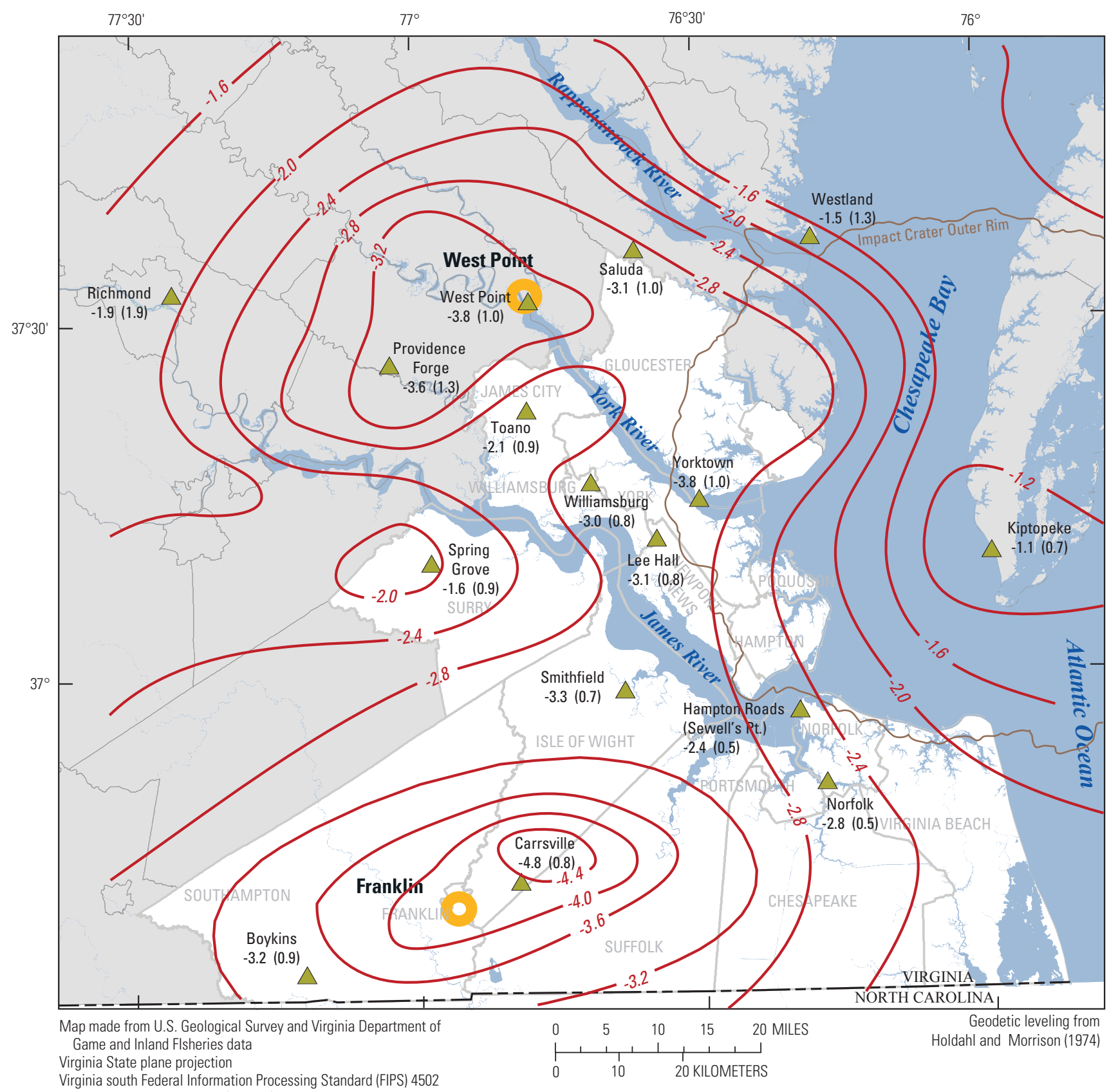

EXPLANATION

\section{$-3.2-$ Line of equal land elevation change rate interpolated from leveling station measurements-Shown in millimeters per year. Interval is variable \\ Groundwater withdrawal center \\ $\triangle$ Leveling station, and land elevation change rate in millimeters $\begin{array}{ll}\text { Boykins } & \text { (0.9) per year (standard deviation) }\end{array}$}

Figure 12. Land elevation change rates from 1940 through 1971. Adapted from Holdahl and Morrison (1974). Contours indicate lines of equal land elevation change rate $(\mathrm{mm} / \mathrm{year})$ and negative elevation change rates indicate subsidence. Values in parentheses are standard deviations. 


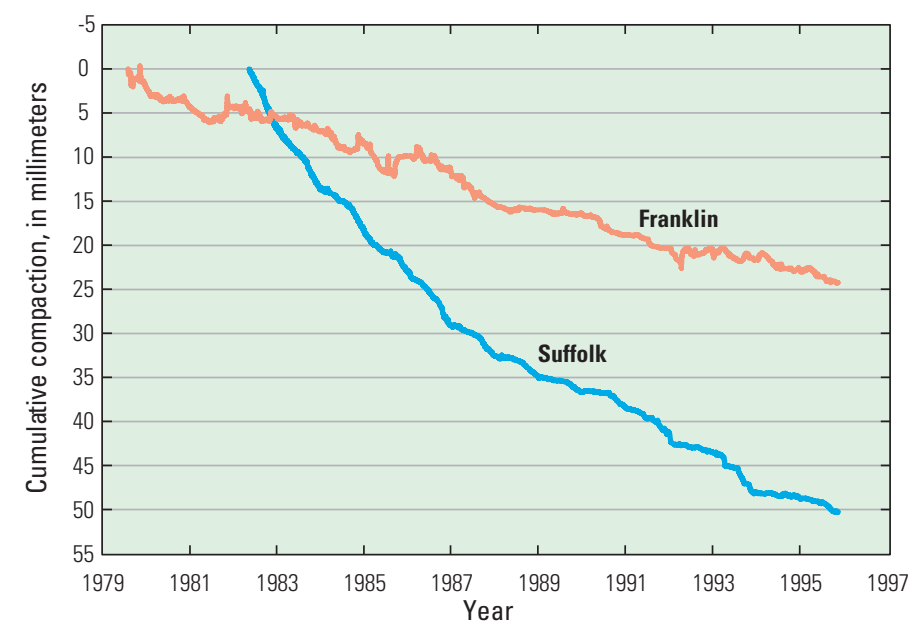

Figure 13. Aquifer-system compaction measured by borehole extensometers in Franklin, Virginia, at U.S. Geological Survey (USGS) site 364101076544802 and in Suffolk, Virginia, at USGS site 364512076343701. Modified from Pope (2002).

\section{Sea-Level Rise and Subsidence in the Southern Chesapeake Bay Region}

Multiple types of data describe land subsidence in the southern Chesapeake Bay region (table 3). There are some inconsistencies between measured subsidence rates, which are expected given the variety of data, the different times of measurement, and the multiple locations measured. However, the data paint a clear overall picture of land subsidence in the region during the past 75 years. Relative sea-level rise has been 3.5 to $4.4 \mathrm{~mm} / \mathrm{yr}$ (table 2). Land subsidence, measured to be 1.1 to $4.8 \mathrm{~mm} / \mathrm{yr}$, causes more than half the relative sea-level rise (fig. 12). Aquifersystem compaction estimated to be 1.5 to $3.7 \mathrm{~mm} / \mathrm{yr}$ can explain the majority of observed land subsidence.

Table 3. Observed sea-level rise and subsidence in the southern Chesapeake Bay region.

[IPCC, Intergovernmental Panel on Climate Change; mm/yr , millimeters per year; NA, not available; NGS, National Geodetic Survey; NOAA, National Oceanic and Atmospheric Administration; SD, standard deviation; USCG, U.S. Coast Guard; USGS, U.S. Geological Survey]

\begin{tabular}{|c|c|c|c|c|c|c|c|c|}
\hline \multirow{2}{*}{ What was measured } & \multirow{2}{*}{$\begin{array}{l}\text { Monitoring } \\
\text { technique }\end{array}$} & \multirow{2}{*}{ Agency } & \multirow{2}{*}{$\begin{array}{c}\text { Number of } \\
\text { stations }\end{array}$} & \multicolumn{5}{|c|}{ Rate, ${ }^{1}$ in $\mathrm{mm} / \mathrm{yr}$} \\
\hline & & & & Period & Average & Low & High & SD \\
\hline \multicolumn{9}{|c|}{ Global data } \\
\hline \multicolumn{9}{|c|}{ Southern Chesapeake Bay region data } \\
\hline Land subsidence & Fixed GPS & $\mathrm{NOAA} / \mathrm{USCG}^{5}$ & 3 & $2006-2011$ & -3.1 & -2.7 & -3.4 & 0.4 \\
\hline Relative sea-level rise & Tidal station & $\mathrm{NOAA}^{6}$ & 4 & $1927-2006$ & 3.9 & 3.5 & 4.4 & 0.2 \\
\hline
\end{tabular}

${ }^{1}$ Negative values indicate downward motion (land subsidence), positive values upward motion.

${ }^{2}$ Data are from Bindoff and others (2007).

${ }^{3}$ Data are from Pope and Burbey (2004).

${ }^{4}$ Data are from Holdahl and Morrison (1974).

${ }^{5}$ Data are from Snay and Soler (2008) and National Geodetic Survey (2013) from Continuously Operating Reference Station (CORS) network

${ }^{6}$ Data are from Zervas (2009). 


\section{Rates of Sea-Level Rise}

Relative sea-level rise measured at four National Oceanic and Atmospheric Administration (NOAA) tidal stations (fig. 2; table 2) averaged $3.9 \mathrm{~mm} / \mathrm{yr}$ from about 1950 through 2006. At the Sewells Point tidal station in Norfolk, Va., rising sea levels have been recorded since 1927 (fig. 14; table 2). Sea level at Sewells Point rose at an average rate of $4.4 \mathrm{~mm} / \mathrm{yr}$ from 1927 to 2006 , with a 95 percent confidence interval of $\pm 0.27 \mathrm{~mm} / \mathrm{yr}$ (Zervas, 2009). In comparison, global average sea levels have been rising at about $1.8 \mathrm{~mm} / \mathrm{yr}$. Although rates of absolute sealevel rise (rise due just to increases in ocean volume) can vary substantially from one location to another and change over time (Boon and others, 2010; Sallenger and others, 2012), the global average rate of $1.8 \mathrm{~mm} / \mathrm{yr}$ from 1961 to 2003 is a widely accepted global benchmark rate (Bindoff and others, 2007, p. 410). The difference between the average sea-level rise computed from the four NOAA tidal stations in the study area $(3.9 \mathrm{~mm} / \mathrm{yr})$ and the benchmark global rate $(1.8 \mathrm{~mm} / \mathrm{yr})$ is $2.1 \mathrm{~mm} / \mathrm{yr}$, which is an estimate of the average rate of land subsidence at the four NOAA stations. These numbers indicate that land subsidence has been responsible for more than half the relative sea-level rise measured in the southern Chesapeake Bay region. Rates of land subsidence vary with location, as can be seen from the different rates of sea-level rise at the four NOAA stations and the variable rates of subsidence measured by Holdahl and Morrison (1974). More research will be required to better understand the details of how land subsidence contributes to relative sea-level rise in this region.

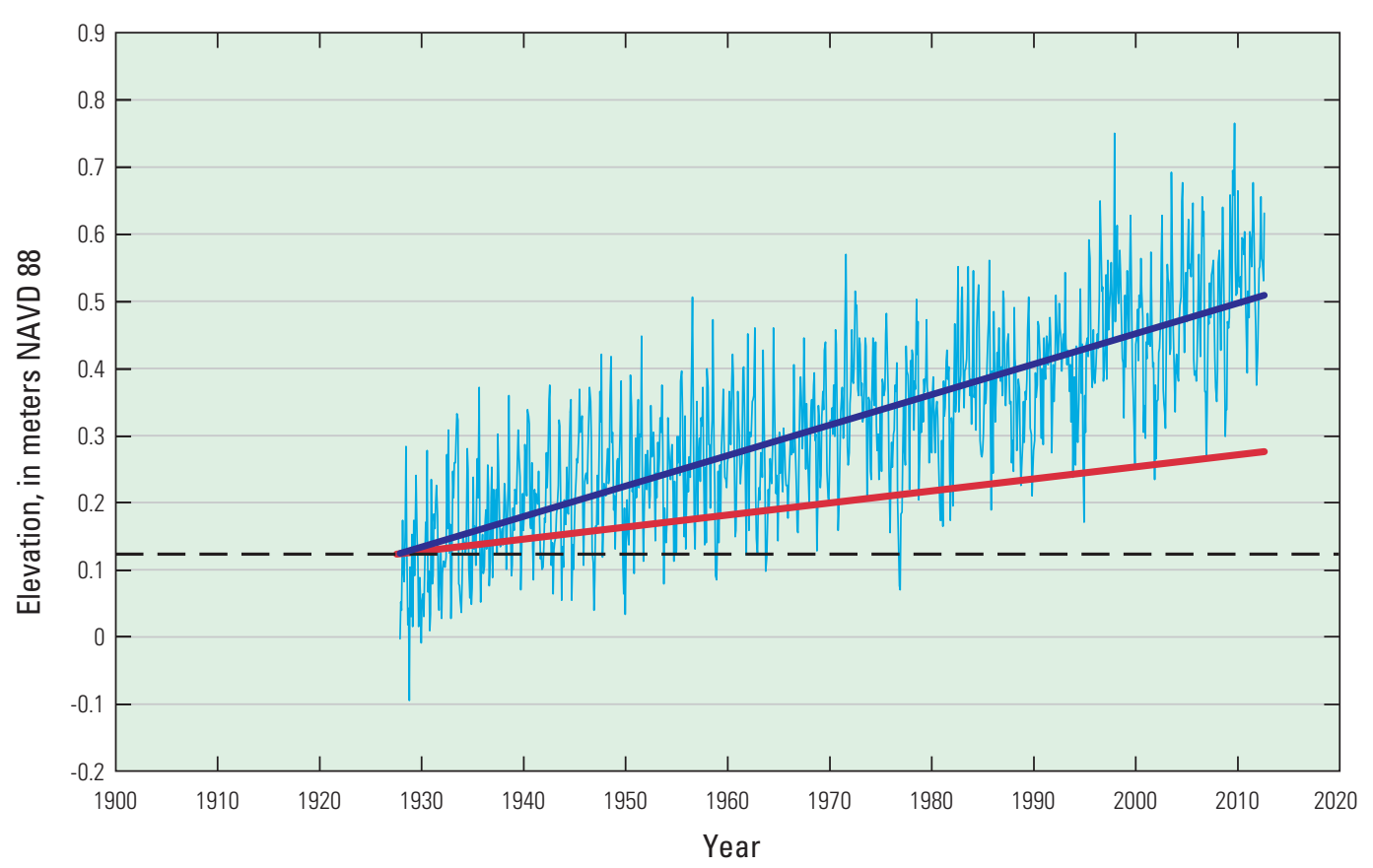

\section{EXPLANATION}

Sewell's Point monthly mean sea level

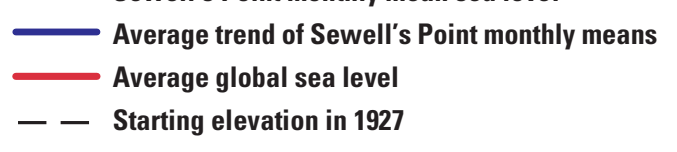

Figure 14. Monthly mean sea levels at Sewells Point in Norfolk, Virginia, at National Oceanic and Atmospheric Administration station 8638610; the global average sea-level rise rate of 1.8 millimeters per year is also shown as a comparison (Bindoff and others, 2007, p. 410). Land subsidence contributes to the high rate of sea-level rise at Sewells Point relative to the average global sea-level rise. 


\section{Links Between Groundwater Withdrawals and Land Subsidence}

Aquifer-system compaction may be responsible for the majority of land subsidence in the southern Chesapeake Bay region based on average measured land subsidence rates of about $2.8 \mathrm{~mm} / \mathrm{yr}$ and measured average compaction rates of $2.6 \mathrm{~mm} / \mathrm{yr}$ (table 3 ). The aquifer-system compaction is caused by high groundwater withdrawal rates that have lowered water levels.

Groundwater withdrawal rates in the region increased sharply in the 20th century (fig. 15) as modern pumping technology was widely adopted (Heywood and Pope, 2009). The many decades of increasing groundwater withdrawals have caused groundwater levels to decrease across the southern Chesapeake Bay region (fig. 9). The water levels in USGS groundwater monitoring well 55H 1 (site 372428076561501 ; fig. 16) give a typical example of water level decreases over time in the Potomac aquifer. Water levels are expected to continue decreasing for many years, even if pumping rates do not increase further, because of delay caused by compressibility of the aquifer system (Konikow and Neuzil, 2007; Mace, 2011).

The complexity of the structure of the aquifer system and the dynamic water-level adjustment to pumping complicate understanding of aquifer-system compaction in the southern Chesapeake Bay region. Because aquifer-system compaction is a major contributor to total land subsidence in the region, an important first step towards understanding land subsidence is to understand compaction. Layer thickness and sediment compressibility vary spatially according to complex stratigraphy in the region, which has been mapped in detail by McFarland and Bruce (2006). Water-level decreases also vary with location (fig. 9) and across the various layers in the aquifer system. To garner a better understanding of land subsidence will likely require construction of a computer model to simulate aquifer-system compaction. Such a model could also be used to estimate future subsidence and examine alternate management scenarios to reduce or mitigate land subsidence.

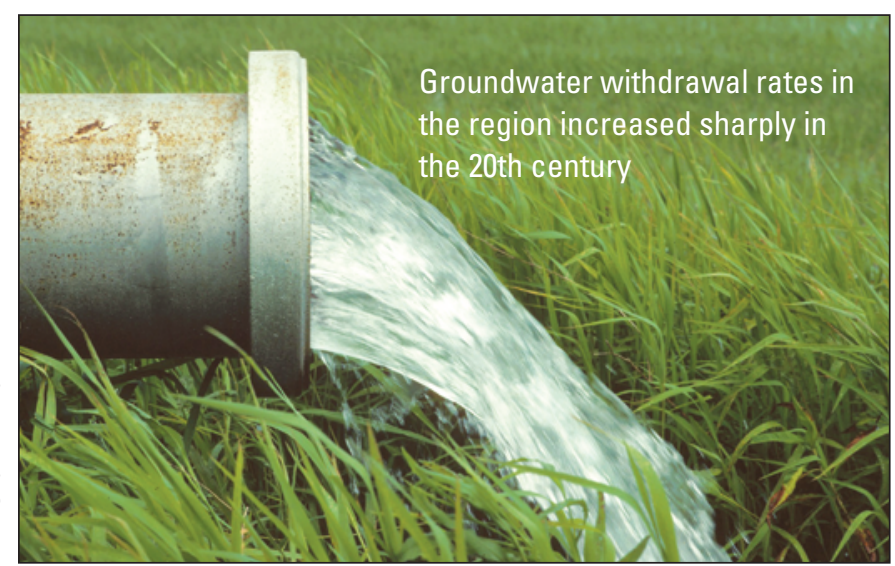

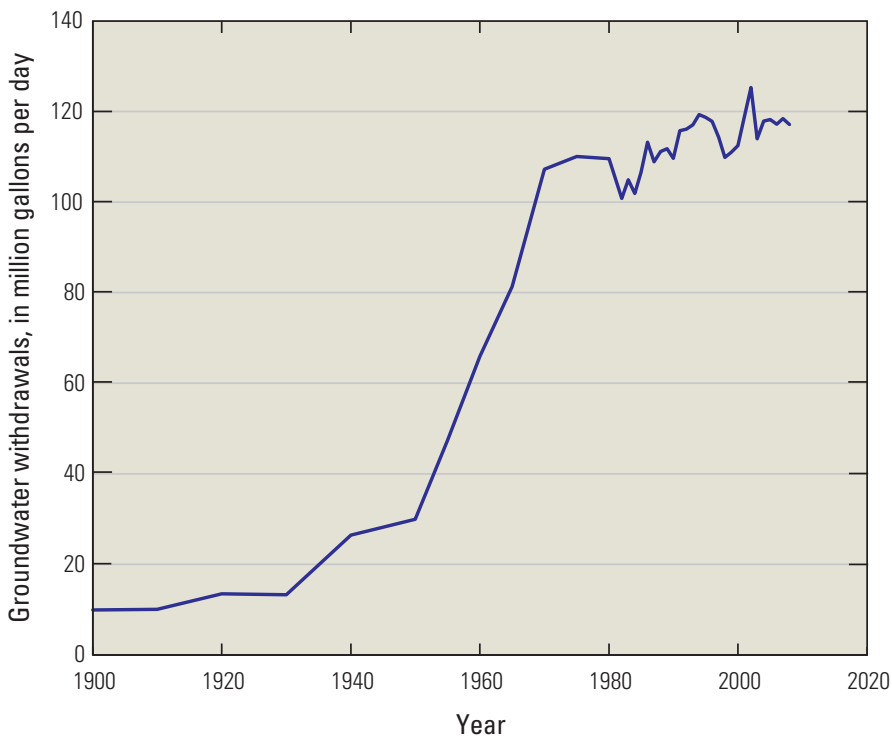

Figure 15. Groundwater withdrawal rates from Virginia Coastal Plain aquifers from 1900 to 2008. Modified from Heywood and Pope (2009).

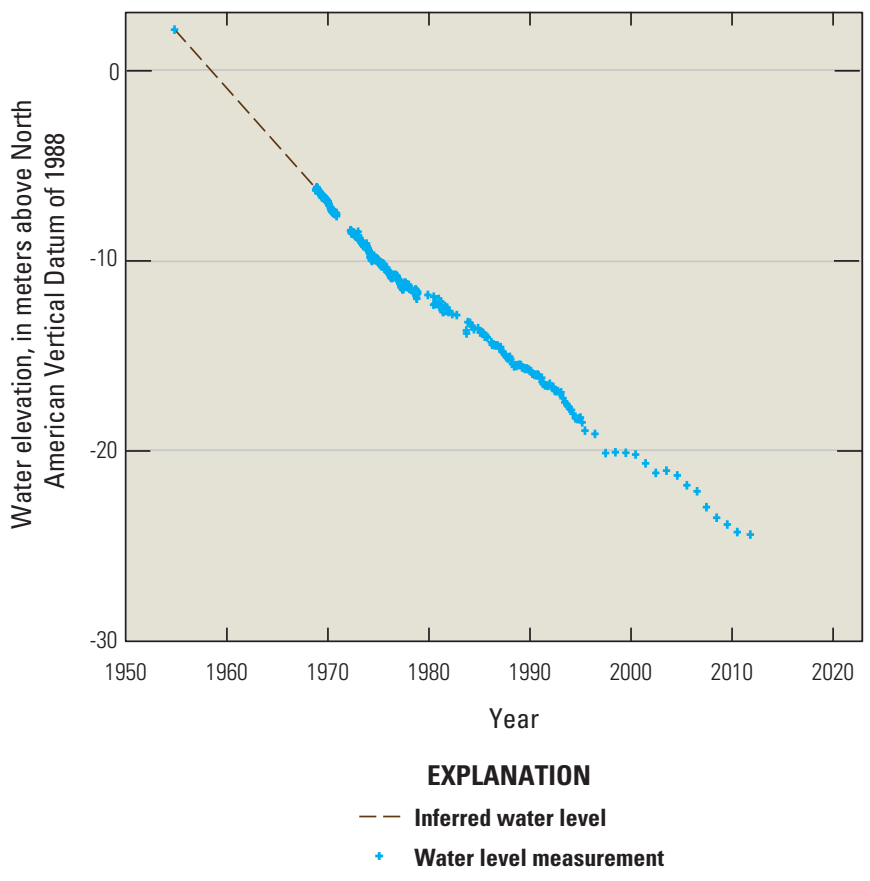

Figure 16. Water levels in the Potomac aquifer at U.S. Geological Survey (USGS) groundwater monitoring well 55H 1 (site 372428076561501) in New Kent County, Virginia. Well location is shown in figure 2. 


\section{Major Conclusions}

- Land subsidence and global sea-level rise combine to cause relative sea-level rise in the southern Chesapeake Bay region.

- Land subsidence causes more than half of the observed relative sea-level rise.

- Aquifer-system compaction causes more than half of the land subsidence.

\section{What Resource Managers Should Know About Land Subsidence in the Southern Chesapeake Bay Region}

The U.S. Geological Survey is cooperating with Federal, State, and local government agencies to study and better understand the problem of land subsidence in the southern Chesapeake Bay region. An emphasis is placed on the vulnerable Hampton Roads communities adjacent to tidal waters of the Chesapeake Bay and Atlantic Ocean. The goal of the cooperative effort is to provide resource managers, planners, and regulators with the knowledge they need to make informed decisions.

\section{Planning for Increased Flood Risks}

Land subsidence can increase flooding risk, as has been seen in the Houston-Galveston area and the Santa Clara Valley. How land subsidence may increase flood risk in southern Chesapeake Bay region, either along the coasts or inland, is not currently well understood. The community of Franklin (fig. 2), where land has subsided and groundwater levels have decreased steeply, experienced extreme flooding along the Blackwater River in 1999 and 2006 (fig. 5). Were these flooding events made worse by land subsidence? It seems likely, but more data and analysis are needed to understand the link between land subsidence and the inland flooding near Franklin and coastal flooding in other Hampton Roads communities. Measurement and mapping could link subsidence to flood inundation and be used in models to forecast flooding potential under different scenarios.

Resource managers in the Hampton Roads area, for example, have begun planning for sealevel rise and associated flood effects (McFarlane and Walberg, 2010, 2011; McFarlane, 2012). Much of the expected relative sea-level rise is unavoidable, and shoreline communities will have to adapt. But an important component of relative sea-level rise, land subsidence, probably could be prevented or reduced in the future if groundwater pumping strategies were changed.

\section{Preventing Land Subsidence}

Future land subsidence caused by aquifer-system compaction can be reduced or stopped by changing water-use practices. Because aquifer-system compaction appears to be the primary cause of land subsidence in the southern Chesapeake Bay region, reducing compaction can potentially reduce land subsidence and associated flood risks. In the Houston-Galveston area and the Santa Clara Valley, resource managers have successfully decreased land subsidence by moving groundwater pumping away from the coast, reducing groundwater withdrawal rates, and increasing aquifer recharge (Galloway and others, 1999). The small contribution to land 
subsidence from glacial isostatic adjustment in the southern Chesapeake Bay region-perhaps about $1 \mathrm{~mm} / \mathrm{yr}$ (Engelhart and others, 2009) — cannot be prevented. This natural glacial isostatic adjustment of the Earth's crust will diminish with time, but at a glacial or geologic pace.

\section{Information Needed to Understand Land Subsidence and Sea-Level Rise}

Although the spatial and temporal details of land subsidence have important consequences to flooding and sea-level rise, the details are not yet well understood in the southern Chesapeake Bay region. Land subsidence varies with location and changes over time, so additional monitoring is needed to better understand these aspects of land subsidence. Particularly along coastlines and in low-lying areas already subject to flooding, it is important to collect data that can improve our understanding of the mechanisms causing land subsidence. Such knowledge can inform long-term infrastructure investments and focus management efforts on the most sensitive areas.

Although aquifer-system compaction is shown to be a major cause of land subsidence in the region, it has been directly measured in only two locations and no extensometer data have been collected since 1995. More data and analyses are needed to provide a foundation of knowledge that can guide resource management decisions. The lack of extensometer data for nearly the past 20 years is a large data gap that hinders our understanding of recent aquifersystem compaction. Detailed measurements of aquifer-system compaction, such as the older extensometer data from Franklin and Suffolk, provide critical information needed to calibrate computer models of land subsidence. Ongoing collection of data is needed to maintain and improve models. Data describing long-term accumulation of land subsidence, best measured by surveying elevations at existing stations such as those used by Holdahl and Morrison (1974), are also useful for calibrating computer models. Obtaining multiple types of data, including airborne or satellite InSAR data, allows different aspects of land subsidence to be seen and better understood.

With appropriate data, maps showing subsidence rates over time in the southern Chesapeake Bay region can be constructed. Such maps would contain valuable information for planners and would also be useful for constructing and calibrating a subsidence simulation model. The model could then be used to predict future land subsidence and to evaluate alternative management scenarios.

\section{Need for Improved Understanding of Land Subsidence in the Region}

Scientific understanding of land subsidence is critical for making informed decisions about public investments and management of land and water resources in the southern Chesapeake Bay region. Many valuable resources, including developed urban centers, coastal marsh and wetland ecosystems, historic sites, and military facilities, are at risk of increased flooding due to land subsidence.

With scientific data as a foundation, basic research on land subsidence and application of that research can improve our understanding of land subsidence and its effect on flooding risks. Monitoring, mapping, and modeling are scientific tools needed to help natural resource managers and urban planners understand and reduce or mitigate land subsidence. Changing resource management practices in response to rising seas and sinking land will require sustained public commitment. We hope that this report will contribute to public awareness of and appreciation for current scientific opinion on the problem of land subsidence in the southern Chesapeake Bay region and provide useful guidance to land- and water-resource managers. Building a strong foundation of scientific understanding can help resource managers make better decisions and help build public confidence in actions taken by managers to address the problem. 


\section{References Cited}

Bawden, G.W., Johnson, M.R., Kasmarek, M.C., Brandt, Justin, and Middleton, C.S., 2012, Investigation of land subsidence in the Houston-Galveston region of Texas by using the global positioning system and interferometric synthetic aperture radar, 1993-2000: U.S. Geological Survey Scientific Investigations Report 2012-5211, 88 p., accessed July 19, 2013, at http://pubs.usgs.gov/sir/2012/5211/.

Bindoff, N.L, Willebrand, Jürgen, Artale, Vicenzo, Cazenave, Anny, Gregory, J.M., Gulev, Sergey, Hanawa, Kimio, Le Quéré, Corrine, Levitus, Sydney, Nojiri, Yukihiro, Shum, C.K., Talley, L.D., and Unnikrishnan, A.S., 2007, Observations - Oceanic climate change and sea level, chap. 5 of Solomon, Susan, Qin, Dahe, Manning, Martin, Chen, Zhenlin, Marquis, Melinda, Averyt, Kristen, Tignor, M.M.B., and Miller, H.L., Jr., eds., Climate change 2007-The physical science basis, Contribution of Working Group I to the fourth assessment report of the Intergovernmental Panel on Climate Change: New York, Cambridge University Press, p. 385-432, accessed April 2013, at http://www.ipcc.ch/pdf/assessmentreport/ar4/wg1/ar4-wg1-chapter5.pdf.

Boon, J.D., Brubaker, J.M., and Forrest, D.M., 2010, Chesapeake Bay land subsidence and sea level change-An evaluation of past and present trends and future outlook: Virginia Institute of Marine Science Special Report 425 in Applied Marine Science and Ocean Engineering, 41 p. plus appendixes, accessed July 19, 2013, at http:/web.vims.edu/GreyLit/ VIMS/sramsoe425.pdf.

Cahoon, D.R., Reed, D.J., Kolker, A.S., Brinson, M.M., Stevenson, J.C., Riggs, Stanley, Christian, Robert, Reyes, Enrique, Voss, Christine, and Kunz, David, 2009, Coastal wetland sustainability, chap. 4 of Titus, J.G., Anderson, K.E., Cahoon, D.R., Gesch, D.B., Gill, S.K., Gutierrez, B.T., Thieler, E.R., and Williams, S.J., eds., Coastal sensitivity to sea-level rise-A focus on the mid-Atlantic region, A report by the U.S. Climate Change Science Program and the Subcommittee on Global Change Research: Washington, D.C., U.S. Environmental Protection Agency U.S. Climate Change Science Program Synthesis and Assessment Product 4.1, p. 57-72.

Chesapeake Bay Program, 2011, State of the Chesapeake Bay program-Summary report to the Chesapeake Executive Council: Annapolis, Maryland, Chesapeake Bay Program, 10 p., accessed March 11, 2013, at http://www.chesapeakebay. net/.

Engelhart, S.E., and Horton, B.P., 2012, Holocene sea level database for the Atlantic Coast of the United States: Quaternary Science Reviews, v. 54, p. 12-25.

Engelhart, S.E., Horton, B.P., Douglas, B.C., Peltier, W.R., and Törnqvist, T.E., 2009, Spatial variability of late Holocene and 20th century sea-level rise along the Atlantic Coast of the United States: Geology, v. 37, no. 12, p. 1115-1118.
Erwin, R.M., Brinker, D.F., Watts, B.D., Costanzo, G.R., and Morton, D.D., 2011, Islands at bay-Rising seas, eroding islands, and waterbird habitat loss in Chesapeake Bay, USA: Journal of Coastal Conservation, v. 15, p. 51-60.

Federal Emergency Management Agency, 2002, Flood insurance study of Franklin, Virginia, community 510060 (revised September 4, 2002): Federal Emergency Management Agency, 16 p.

Galloway, D.L., and Hoffmann, Jörn, 2007, The application of satellite differential SAR interferometry-derived ground displacements in hydrogeology: Hydrogeology Journal, v. 15 , no. 1 , p. $133-154$.

Galloway, D.L., Jones, D.R., and Ingebritsen, S.E., eds., 1999, Land subsidence in the United States: U.S. Geological Survey Circular 1182, 177 p., accessed July 19, 2013, at http://pubs.usgs.gov/circ/circ1182/.

Gutierrez, B.T., Williams, S.J., and Thieler, E.R., 2009, Ocean coasts, chap. 3 of Titus J.G., Anderson, K.E., Cahoon, D.R., Gesch, D.B., Gill, S.K., Gutierrez, B.T., Thieler, E.R., and Williams, S.J., eds., Coastal sensitivity to sea-level riseA focus on the mid-Atlantic region, A report by the U.S. Climate Change Science Program and the Subcommittee on Global Change Research: Washington, D.C., U.S. Environmental Protection Agency U.S. Climate Change Science Program Synthesis and Assessment Product 4.1, p. 43-56.

Heywood, C.E., and Pope, J.P., 2009, Simulation of groundwater flow in the Coastal Plain aquifer system of Virginia: U.S. Geological Survey Scientific Investigations Report 2009-5039, 115 p., accessed July 19, 2013, at http://pubs. usgs.gov/sir/2009/5039/.

Holdahl, S.R., and Morrison, N.L., 1974, Regional investigations of vertical crustal movements in the U.S., using precise relevelings and mareograph data: Tectonophysics, v. 23, no. 4, p. 373-390.

Kirwan, M.L., and Guntenspergen, G.R., 2012, Feedbacks between inundation, root production, and shoot growth in a rapidly submerging brackish marsh: Journal of Ecology, v. 100, no. 3, p. 764-770.

Kirwan, M.L., Langley, J.A., Guntenspergen, G.R., and Megonigal, J.P., 2012, The impact of sea-level rise on organic matter decay rates in Chesapeake Bay brackish tidal marshes: Biogeosciences Discussions, v. 9, no. 10, p. 14689-14708.

Konikow, L.F., and Neuzil, C.E., 2007, A method to estimate groundwater depletion from confining layers: Water Resources Research, v. 43, no. 7, W07417, 15 p.

Mace, R.E., 2011, Peer review of Virginia's groundwater management program: Virginia Department of Environmental Quality final report, December, $19 \mathrm{p}$.

McFarland, E.R., and Bruce, T.S., 2006, The Virginia Coastal Plain hydrogeologic framework: U.S. Geological Survey Professional Paper 1731, 118 p., 25 pls., accessed July 19, 2013, at http://pubs.water.usgs.gov/pp1731/. 
McFarlane, B.J., 2012, Climate change in Hampton RoadsPhase III-Sea level rise in Hampton Roads, Virginia: Chesapeake, Virginia, Hampton Roads Planning District Commission report PEP12-06, July, 102 p. plus maps, accessed July 19, 2013, at http://www.hrpdcva.gov/uploads/docs/HRPDC ClimateChangeReport2012_Full_Reduced.pdf.

McFarlane, B.J., and Walberg, E.J., 2010, Climate change in Hampton Roads - Impacts and stakeholder involvement: Chesapeake, Virginia, Hampton Roads Planning District Commission report PEP10-02, February, 43 p., accessed July 19, 2013, at http://www.hrpdcva.gov/uploads/docs/Climate Change_Final_Report_All.pdf.

McFarlane, B.J., and Walberg, E.J., 2011, Climate change in Hampton Roads-Phase II-Storm surge vulnerability and public outreach: Chesapeake, Virginia, Hampton Roads Planning District Commission report PEP12-06, June, 79 p., accessed July 19, 2013, at http://www.hrpdcva.gov/uploads/ docs/HRPDC_ClimateChange2010_FINAL.pdf.

Morris, J.T., Sundareshwar, P.V., Nietch, C.T., Kjerfve, Björn, and Cahoon, D.R., 2002, Responses of coastal wetlands to rising sea level: Ecology, v. 83, no. 10, p. 2869-2877.

National Geodetic Survey, 2013, IGS08 geodetic CORS positional antennae reference point (ARP) [GRS80 ellipsoid] computed velocities: National Oceanic and Atmospheric Administration, [March 2], accessed March 3, 2013, at ftp:// cors.ngs.noaa.gov/cors/coord/coord_08/igs08_geo.comp.txt.

Poland, J.F., ed., 1984, Guidebook to studies of land subsidence due to ground-water withdrawal: United Nations Educational, Scientific, and Cultural Organization, 305 p. plus appendixes. (Also available at http://wwwrcamnl.wr.usgs.gov/rgws/ Unesco/PDF-Chapters/Guidebook.pdf.)

Pope, J.P., 2002, Characterization and modeling of land subsidence due to groundwater withdrawals from the confined aquifers of the Virginia Coastal Plain: Virginia Polytechnic Institute M.S. thesis, $153 \mathrm{p}$.

Pope, J.P., and Burbey, T.J., 2004, Multiple-aquifer characterization from single borehole extensometer records: Ground Water, v. 42 , no. 1 , p. $45-58$.

Powars, D.S., and Bruce, T.S., 1999, The effects of the Chesapeake Bay impact crater on the geological framework and correlation of hydrogeologic units of the lower York-James Peninsula, Virginia, U.S. Geological Survey Professional Paper 1612, 82 p.
Pritchard, M.E., 2006, InSAR, a tool for measuring Earth's surface deformation: Physics Today, v. 59, no. 7, July, p. 68-69.

Raucoules, D., Bourgine, B., de Michele, M., Le Cozannet, G., Closset, L., Bremmer, C., Veldkamp, H., Tragheim, D., Bateson, L., Crosetto, M., Agudo, M., and Engdahl, M., 2009, Validation and intercomparison of persistent scatterers interferometry - PSIC4 project results: Journal of Applied Geophysics, v. 68, no. 3, p. 335-347.

Sallenger, A.H., Doran, K.S., and Howd, P.A., 2012, Hotspot of accelerated sea-level rise on the Atlantic Coast of North America: Nature Climate Change, v. 2, no. 12, p. 884-888.

Saunders, Stephen, Easley, Tom, and Spencer, Theo, 2010, Virginia special places in peril—Jamestown, Chincoteague, and Shenandoah threatened by climate disruption: Louisville, Colorado, The Rocky Mountain Climate Organization and New York, New York, Natural Resources Defense Council, $41 \mathrm{p}$.

Sella, G.F., Stein, Seth, Dixon, T.H., Craymer, Michael, James, T.S., Mazzotti, Stephane, and Dokka, R.K., 2007, Observation of glacial isostatic adjustment in "stable" North America with GPS: Geophysical Research Letters, v. 34, no. 2, L02306, $6 \mathrm{p}$.

Snay, R.A., and Soler, Tomás, 2008, Continuously operating reference station (CORS) - History, applications, and future enhancements: Journal of Surveying Engineering, v. 134, no. 4, November 1, p. 95-104.

Sneed, Michelle, Stork, S.V., and Ikehara, M.E., 2002, Detection and measurement of land subsidence using global positioning system and interferometric synthetic aperture radar, Coachella Valley, California, 1998-2000: U.S. Geological Survey Water-Resources Investigations Report 02-4239, 29 p. (Also available at http://pubs.usgs.gov/wri/wri024239/.)

Stork, S.V., and Sneed, Michelle, 2002, Houston-Galveston Bay area, Texas, from space-A new tool for mapping land subsidence: U.S. Geological Survey Fact Sheet 2002-110, 6 p., http://pubs.usgs.gov/fs/fs-110-02/.

U.S. Census Bureau, 2010, Virginia-2010-Population and housing unit counts: U.S. Census Bureau 2010 Census of Population and Housing CPH-2-48, accessed April, 2013, at http://www.census.gov/prod/cen2010/cph-2-48.pdf.

Zervas, Chris, 2009, Sea level variations of the United States, 1854-2006: National Oceanic and Atmospheric Administration Technical Report NOS CO-OPS 053, 76 p. plus appendixes, accessed July 19, 2013, at http://www.co-ops.nos.noaa. gov/publications/Tech_rpt_53.pdf. 


\author{
To obtain more \\ Information about land subsidence and water \\ resources in Virginia, visit \\ http://va.water.usgs.gov/ \\ or contact: \\ Director \\ U.S. Geological Survey \\ Virginia Water Science Center \\ 1730 East Parham Road \\ Richmond, VA 23228
}

A barge transporting chemicals is pushed to port by tugboat along the Elizabeth River in Norfolk, Virginia. Photograph by The' N. Pham, The Virginian-

Pilot, February 2013, used with permission. 
Prepared by the Pembroke Publishing Service Center.

For more information concerning this report, contact:

Director

U.S. Geological Survey

Virginia Water Science Center

1730 East Parham Road

Richmond, VA 23228

or visit our Web site at:

http://va.water.usgs.gov 


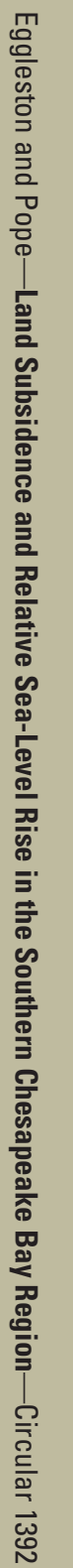

